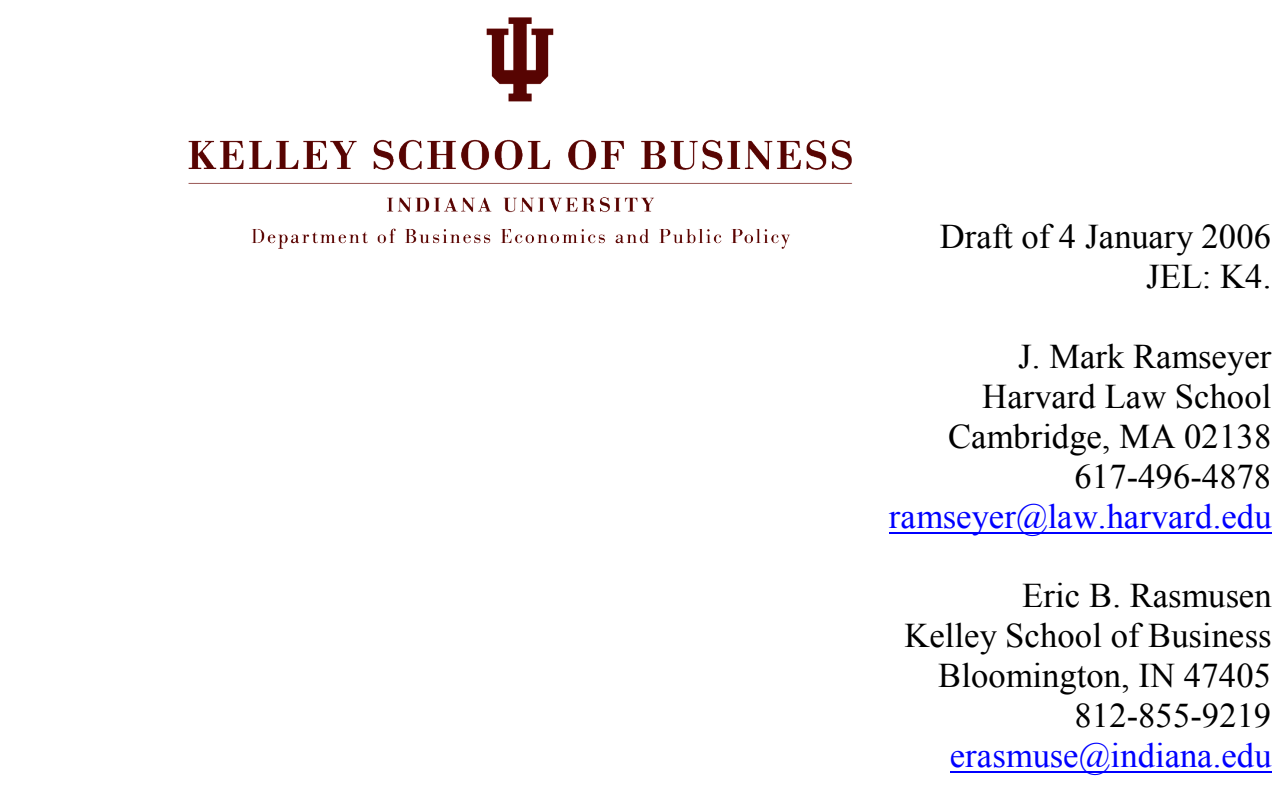

\title{
The Case for Managed Judges: Learning from Japan after the Political Upheaval of 1993
}

\author{
By J. Mark Ramseyer \& Eric B. Rasmusen*
}

\begin{abstract}
Although the executive branch appoints Japanese Supreme Court justices as it does in the United States, a personnel office under the control of the Supreme Court rotates lower court Japanese judges through a variety of posts. This creates the possibility that politicians might indirectly use the postings to reward or punish judges. For forty years, the Liberal Democratic Party (LDP) controlled the legislature and appointed the Supreme Court justices who in turn controlled the careers of these lower-court judges. In 1993, it temporarily lost control. We use regression analysis to examine whether the end of the LDP's electoral lock changed the court's promotion system, and find surprisingly little change. Whether before or after 1993, the Supreme Court used the personnel office to "manage" the careers of lower court judges. The result: uniform and predictable judgments that economize on litigation costs by facilitating out-of-court settlements.
\end{abstract}

* Mitsubishi Professor of Japanese Legal Studies, Harvard Law School, and Dan R. and Catherine M. Dalton Professor, Kelley School of Business, Indiana University. We gratefully acknowledge the helpful comments and suggestions of Stephen Burbank, Thomas Ginsburg, John Haley, Joanna Shepherd, Curtis Milhaupt, Mark West, and the audiences of workshops at Emory Law School and the University of Pennsylvania Law School, and the financial assistance of the John M. Olin Center for Law, Economics \& Business at the Harvard Law School.

This article is forthcoming in The University of Pennsylvania Law Review. 
The Chief Justice of the United States supervises a vast judicial bureaucracy. He is the titular head of the Judicial Branch: 1200 judges with life tenure, plus 850 magistrate and bankruptcy judges and 30,000 administrative staff members. The careers he can affect most are those of his administrative employees. Even the life-tenured judges, however, he can appoint to specialized judicial bodies. In doing all this, he supervises the federal Judicial Conference with its budget of $\$ 5.4$ billion. ${ }^{1}$

If the Chief Justice of the U.S. does much, his counterpart in Japan does much more. Not only does he supervise the administrative employees, he also supervises the judicial personnel office called the Secretariat. In turn, the judges in the Secretariat control the jobs of the 3,000 other national judges who decide cases (there are no prefectural judges, analogous to state judges in the United States). The American Chief Justice does not tell lower court judges where to sit (though see Section III, below). Through the Secretariat, the Japanese Chief Justice does. The American Chief Justice does not decide how much the lower court judges earn. Through the Secretariat, the Japanese Chief Justice does. Effectively, the Chief Justice exercises power over the career of every lower court judge. All this he does as an appointee of a distinctly political Prime Minister.

This is not an institutional structure likely to foster judicial independence. Nor over the four decades that the Liberal Democratic Party (LDP) ran Japan did the party care to foster independence. Instead, the Chief Justices supervised the courts in ways that furthered the electoral interests of the LDP. Over time, litigants allied with opposition parties filed a variety of politically sensitive legal challenges. When a judge decided one of their cases along the lines the opposition wanted, he tended to suffer in his career.

The LDP temporarily lost power in 1993, and politicians from other parties took control. Although the LDP reclaimed the government in 1996, it had lost its electoral lock, and now needed to consider the possibility that it might again find itself in the opposition. Throughout the ensuing instability, however, the courts retained their tightly controlled, conservative structure. Smarter and harder working judges did better than the (relatively) dull and indolent. Those who served as loyal "organization men" did better than renegades who had allied themselves with the left.

Whether in Japan or in the U.S., university professors and bar activists express dismay at court systems so susceptible to control from the top. Yet their dismay misses much of the point. In Japan, these incentives place judges within a brutally competitive internal labor market. Through the resulting incentives, the Chief Justice effectively imposes on the judges stringently uniform standards. That uniformity, in turn, enables disputants to settle their disputes out of court by the expected litigated outcome.

Through its system of "managed judges," in other words, Japan has created a system that lets people resolve their disputes by looking to uniform and predictable legal standards. The standards remain uniform and predictable because the judges who impose them have far more incentive than American judges to keep them that way. The predictability creates less need for lawyers to discover and argue the law. In turn, it lets

${ }^{1}$ Judith Resnik \& Theodore Ruger, One Robe, Two Hats -- A Commentary, N.Y. Times, July 17, 2005; Theodore W. Ruger, The Judicial Appointment Power of the Chief Justice, 7 U. Pa. J. Const. L. 341,343, 358-67 (2004). 
Japanese taxpayers use law and courts with far fewer lawyers than taxpayers in the United States. In short, Japan has used these incentives to slash the transactions costs that American lawyers, juries, and judges magnify so remorselessly.

The political costs to Japan of having "managed judges" are trivial. The vast majority of cases involve no issues of political moment. Whether in Japan or the U.S., most legal disputes instead concern such things as traffic accidents and debt collection. What is more, the LDP was before 1993 the majority party anyway. Even in those rare political cases when judges furthered LDP electoral interests, usually they just gave Japanese voters what they wanted from their government.

In this article, we detail the structure of the Japanese courts and use statistical analysis to see if the promotion structure changed after the LDP lost power in 1993. We start by laying out the institutional structure and explaining where political influence entered and did not enter before 1993 (Section I.A.). We then describe the events of 1993 and how they might have affected the behavior of the courts (I.B.). After doing so, we look quantitatively at both the Supreme Court and the lower courts to see what actually happened (I.C.). We conclude with a summary and fuller discussion -necessarily more speculative than the rest of the paper -- of the advantages and disadvantages of this system of managed judges (II.).

\section{Structure and Implementation}

A. The Pre-1993 Tradition: ${ }^{2}$

1. Institutional structure. -- (a) The Secretariat. At the apex of the Japanese courts stands the Chief Justice of the fifteen-member Supreme Court. Appointed by the Prime Minister, he participates in judicial decision-making. He presides over the Judicial Conference, the justices of the Supreme Court meeting on matters of rulemaking and judicial administration. And he runs the court's administrative office, the Secretariat.

In running the Secretariat, the Chief Justice runs an institution he knows well, especially compared to most of his fellow justices. From 1973 to 2003, a plurality of the 82 Supreme Court appointees had been career judges before joining the Court, but a majority had not. During the same period, every Chief Justice had been a career lowercourt judge. Of the five Chief Justices appointed since 1983 (we lack career data on the earlier Justices), each had worked in the Secretariat himself while a lower-court judge. Three of the five had even headed it as the Secretary General (see Tables 1 and 2). If we look beyond just the Chief Justice to all 20 post-1983 justices appointed from the lower courts, we find 7 who had earlier served as Secretary General of the Secretariat, and

\footnotetext{
${ }^{2}$ We base this discussion on our earlier work. That work began with a series of articles: J. Mark Ramseyer \& Eric B. Rasmusen, Why Are Japanese Judges so Conservative in Politically Charged Cases?, 95 Am. Pol. Sci. Rev. 331 (2001); J. Mark Ramseyer \& Eric B. Rasmusen, Why Is the Japanese Conviction Rate so High?, 30 J. Legal Stud. 53 (2001); J. Mark Ramseyer \& Eric Rasmusen, Skewed Incentives: Paying for Politics as a Japanese Judge, Judicature, 190 (Jan.-Feb. 2000); J. Mark Ramseyer \& Eric B. Rasmusen, Why the Japanese Taxpayer Always Loses, 72 S. Cal. L. Rev. 571 (1999); J. Mark Ramseyer \& Eric B. Rasmusen, Judicial Independence in a Civil Law Regime: The Evidence from Japan, 13 J. Law, Econ. \& Org. 259 (1997). We then collected this material into a book: J. Mark Ramseyer \& Eric B. Rasmusen, Measuring Judicial Independence: The Political Economy of Judging in Japan (Chicago: University of Chicago Press, 2003). Our citations to Ramseyer \& Rasmusen, below, refer to this book.
} 
another 9 had worked there in other capacities. Only 4 had never worked in the Secretariat. $^{3}$

Justices appointed from positions outside the court system would, of course, lack such experience and therefore have less power over the careers of lower-court judges. These include university professors, prosecutors, lawyers in private practice, and 12 bureaucrats. Of the last group, five had headed the Cabinet Legislation Bureau, five were former diplomats, and one each came from the ministries of labor and of health and welfare. ${ }^{4}$

[Insert Table 1 about here.]

[Insert Table 2 about here.]

Like other Supreme Court justices, the Chief Justice serves until mandatory retirement at age 70. In theory, voters can recall him and his Supreme Court colleagues at a general parliamentary election. In practice, they do not, and have never even come close. The justices' jobs are secure. ${ }^{5}$

Not so the jobs of lower court judges. To a Japanese judge the Secretariat represents what the Vatican is to an ambitious Catholic priest: the ultimate locus of control over their careers. Japanese judges join the court young. Rather than being appointed in mid-career as in the U.S., they join right after completing their legal training at the national law school, the Legal Research \& Training Institute (LRTI). Because for years the Institute entrance exam had a 1-3 percent pass rate (it is higher today), most judges flunked it several times before starting the LRTI (Table 3, Panel D.). As a result, by the time they joined the court most were in their late $20 \mathrm{~s}$.

[Insert Table 3 about here.]

Lower-court judges serve a series of 10-year terms. Although the Secretariat can choose not to reappoint them at the end of each term, it almost invariably does. Judges face mandatory retirement at age 65 , but most retire at about $60 .^{6}$

Judges sit where the Secretariat tells them to sit. Ostensibly to train the young judges, to avoid corruption, and to equalize the quality of provincial courts, the Secretariat moves judges from post to post at regular intervals, typically of three years. These moves can be and often are from one end of Japan to the other, and from trial courts to appellate courts and back again. The Secretariat also decides their pay via promotions. Although the Constitution does protect judges against pay cuts, it does not promise them pay raises. Judicial salaries range widely, and the Secretariat decides how fast they climb the scale. ${ }^{7}$

\footnotetext{
${ }^{3}$ Here and elsewhere, we obtain our data on the Japanese judiciary from Nihon minshu horitsuka kyokai, ed., Zen saibankan keireki soran dai 4 ban [Overview of Careers of All Japanese Judges, 4th ed.] (Tokyo: Konin sha, 2004).

${ }^{4}$ John O. Haley, The Japanese Judiciary: Maintaining Integrity, Autonomy, and the Public Trust, in Daniel Foote, ed., Law in Japan: A Turning Point? (Seattle: University of Washington Press: forthcoming 2007), at 9.

${ }^{5}$ Saibansho ho [Courts Act], Law No. 59 of 1947, Sec. 50 (retirement age); J. Mark Ramseyer \& Frances McCall Rosenbluth, Japan's Political Marketplace, Rev. ed. 152-53 (Cambridge: Harvard University Press, 1997) (recalls).

${ }^{6}$ Courts Act, supra note, at Sec. 50 (mandatory retirement age); Ramseyer \& Rosenbluth, supra note, at 154 (retirement practice), $156 \& 165$ (non-reappointment incidents).

${ }^{7}$ Ramseyer \& Rosenbluth, supra note, at 155 (pay scale); Ramseyer \& Rasmusen, supra note, at 40-43 (determinants of pay)
} 
The Supreme Court also differs from lower courts in how readily the heterodox can express their views. By law, each Supreme Court justice must give his own opinion in a Supreme Court case. ${ }^{8}$ Hence, published cases include dissenting opinions as well as majority opinions and dissenting votes. In the lower courts, dissenting judges on a panel do not publish separate opinions. They cannot try to express their views and modify the law by the eloquent presentation of their arguments.

(b) The hierarchy of posts. Not all posts are created equal. Usually, a judge wants a job in one of the major metropolitan areas, and in Tokyo if possible. American visitors may delight in the mountain towns and seaside villages of the Japanese countryside, but ambitious Japanese professionals stick to Tokyo. Tokyo houses the national government. It houses the Supreme Court and the Secretariat. It represents the locus of the opposition parties. It contains most of the professional, civic, and non-profit organizations. It houses the headquarters of most large corporations. It is the site of the best universities. And crucially for professionals with families, it has most of the best preparatory schools.

Judges also want judgeships with administrative power. After about 22 years, they can expect a "sokatsu" posting -- a judgeship with personnel responsibilities over their local court. ${ }^{9}$ Before retiring, some can expect to serve as a District Court Chief Judge. And the most successful will become Chief Judge of one of the seven High Courts (the appellate courts). ${ }^{10}$

Most judges covet certain non-judicial jobs as well. Perhaps the most prestigious such posting is to the Secretariat itself. There, a judge may handle personnel rotations, set court policy, or write rough drafts of Supreme Court opinions. Other judges may work at a prosecutorial office. They may teach future lawyers and judges at the LRTI. Or they might spend a few years at the Civil Affairs Bureau of the Ministry of Justice.

The same ambitious judges will shun the family courts, summary courts, and judicial branch offices when they can. Branch offices tend to be in the smaller cities, and have only one or a very few judges. Even promising judges will spend some time in a branch office, but fast-track judges will have fewer such rotations than others. Summary courts (i.e., small claims courts) represent a separate structure entirely, and most summary court judges are not part of the judicial hierarchy at all. Still, a standard judge on a slow track can occasionally find himself exiled to summary court duty for several years.

Reflecting the prestige of Tokyo posts, the Secretariat every year chooses from its new recruits the most promising and names them to the Tokyo District Court (TDC; see Table 3, Pan. E). Typically, that appointment places the judge on a fast track. Should he work shrewdly and prudently, he will earn more rotations through prestigious posts (and fewer in branch offices) than his colleagues for the rest of his career. The Secretariat also determines which new judges are least promising, and until recently (but no longer) named them to an initial appointment at a branch office or summary court (Table 3, Pan. F).

\footnotetext{
${ }^{8}$ Courts Act, supra note, at Sec. 11.

${ }^{9}$ Ramseyer \& Rasmusen, supra note, at 40 (years to sokatsu).

${ }^{10}$ Ramseyer \& Rosenbluth, supra note, at 166 (highest career jobs).
} 
Take the career of a fairly successful judge, Keiichi Konagamitsu. A native of the southern provincial city of Fukuoka, Konagamitsu attended the prestigious University of Kyoto, typically ranked second only to the University of Tokyo (see Table 3, Pans. B and C). He graduated from the LRTI in 1965, and went to work at the District Court in the urban center of Okayama. Given that he was born in 1936, he probably graduated from the university in 1958. Since he entered the LRTI in 1963, he apparently failed the LRTI entrance exam five times (compare Table 3, Pan. D).

Konagamitsu's first rotation after his three years in Okayama took him to the TDC. Another three years there, and he went to provincial Niigata. After yet another three years, he returned to Tokyo, and four years later (at age 42) moved to his home of Fukuoka. Other than a few years teaching at the Tokyo-based LRTI, he spent most of the rest of his career in Fukuoka. After serving as Chief Judge of the Fukuoka District Court for 18 months, he retired in 2001 at age 65.

Over this elaborate hierarchy presides the Chief Justice. He supervises the Secretary General of the Secretariat. The Secretary General is himself on a fast track, and may join the Supreme Court within a few years. He supervises the judges staffing the Secretariat, and those Secretariat judges monitor the performance of the rest. They decide who will move where at the end of each three-year stint and how quickly to promote each judge on the pay scale.

2. Implementation..$^{11}$-- During most of the post-War years, the Secretariat moved judges neither uniformly nor randomly. Instead, it promoted the talented more quickly than the dull, and the industrious more quickly than the indolent (if we may use such terms comparatively -- all who pass the LRTI examination form an elite group). Through a series of empirical studies using multivariate regressions, we examined the gist of this system as it operated through the late 1980s. Here is what we found.

First, the Secretariat favored judges from the most selective universities. Because these schools maintain the most selective entrance examinations, their graduates tend to be smarter and harder working than others. Not surprisingly, then, judges from these schools tend to obtain the best jobs at the outset, to obtain better posts over the course of their careers, and to climb the pay scale most rapidly.

Second, the Secretariat favored the judges who passed the entrance examination to the LRTI most quickly. Within the contemporary bar, students who pass the exam on one of their first tries obtain the coveted jobs at the highest-paying law firms. Within the courts, we found that those who passed it early landed the best initial posts, obtained the more prestigious jobs over the next several decades, and climbed the pay scale most quickly.

\footnotetext{
${ }^{11}$ The discussion in Sections 2 and 3 below is based on Ramseyer \& Rasmusen, supra note. This empirical work generated two spirited responses from John Haley: John O. Haley, Review, 30 Journal of Japanese Studies 235 (2004); Haley, supra note; see also John O. Haley, Judicial Independence in Japan Revisited, 25 Law in Japan 1 (1995). Frank Upham's summary and critique of the exchange appears in Frank K. Upham, Political Lackeys or Faithful Public Servants: Two Views of the Japanese Judiciary, _ L Law \& Social Inquiry 421 (2005).

As we understand Haley's views, he does not contest our description of the institutional framework, does not contest the way that the Secretariat has enforced it in the apolitical context, and does not object to our characterization of the outcome of most politically sensitive cases as pro-LDP. Instead, he objects to our use of principal-agent theory to attribute that pro-LDP bias to LDP politicians. He emphasizes their lack of overt intervention, and the institutional freedom of the Supreme Court to control the lower courts as it wished.
} 
Third, judges who did well early in their careers tended to do well later. Even if we control for other measures of performance, those judges posted initially to the TDC continued to obtain better than average posts throughout their career. They obtained pay raises more quickly as well.

Fourth, although the evidence is more haphazard, the judges who published the most opinions tended to obtain better jobs. And last, men seem to have climbed the pay scale more quickly than women.

3. Political bias. -- This institutional structure creates an obvious potential for political bias. The Prime Minister appoints the Chief Justice. The Chief Justice supervises the Secretary General, the Secretary General runs the Secretariat, and the Secretariat decides which judges obtain the best jobs and quickest raises. By appointing as Chief Justice men who shared his preferences, the Prime Minister could inject a political bias into the administration of the courts. Given mandatory retirement of justices at age 70, he might not have long to wait. As Table 2 shows, Prime Minister Koizumi was able to appoint eight members of the Supreme Court, a majority, within two years of taking office.

By basic principal-agent theory, whether the Prime Minister overtly intervened in the courts is beside the point. The stereotypical English lord did not need to remind a good butler what he wanted done. Good butlers knew what their masters wanted and did it before the master asked. Indeed, the master only cared about results, and was glad to delegate details to the butler. To be sure, if a Prime Minister never intervened in the courts, that fact could indicate that he lacked the power to do so. Yet in Japan the institutional structure gave him full power to choose a Chief Justice who would enforce his political preferences on the courts. If he never intervened, that lack of intervention more likely indicates that his appointees in the courts knew what he wanted done, and did it without his needing to ask.

Granted, the Prime Minister's power over the courts was indirect and slow. His was the power to appoint, not the power to fire. In turn, the Chief Justice's power was the power to promote or withhold promotion, not the power to punish a wayward judge immediately. The LDP had long controlled the Parliament, and expected to continue to control it. Ultimately, indirect power was apparently enough: overwhelmingly, the courts did promote the electoral interests of the LDP.

The leaders of the LDP were not ideologues trying to leave a legacy of social change and progressive legislation. They were politicians who wanted to please voters and the business community, and a majority of voters and businesses wanted steady and continuing economic growth. Toward that end, LDP leaders did not want courts that tried to change society -- if they wanted a new legal rule, as leaders of the majority party they could implement a change through a statute. They wanted courts that would administer the law efficiently and stay out of the way. And, of course, staying out of the way included staying out of the way of government policies, rather than introducing awkward questions of constitutionality.

Thus, the LDP wanted two things from the courts: for judges to keep their political views out of their opinions, and to refrain from invoking the Constitution when doing so would offend the LDP. These considerations suggest that Japanese courts may not always have been politically neutral on questions of constitutionality. To test that 
neutrality before 1993, we examined a series of politically charged disputes. Again using multivariate regressions, we consistently found that those lower-court judges who decided the cases in the way that LDP leaders wanted tended to obtain better jobs in the decade after the decision than those judges who flouted those preferences.

We also examined the careers of the several hundred judges who, in the 1960s, joined the left-leaning Young Jurists League (YJL). ${ }^{12}$ Judges who joined the League tended to suffer in their careers. All else equal, they obtained less attractive positions than their peers. Concomittantly, they earned pay raises more slowly than those peers.

\section{B. Potential Change:}

1. The chaos of 1993. -- Nineteen ninety three was a bad year for the LDP. After dominating politics for nearly four decades, it entered the 1990's facing a massive range of problems. Having championed enormously expensive public-works projects for years, it had in 1988 imposed a national sales tax that alienated a broad range of voters. Under pressure from the U.S., it instituted trade and investment reforms that threatened key party constituents. With the end of the Cold War, its broadly capitalist constituency began to unravel. As rural Japanese continued to migrate to the cities, its agricultural base steadily atrophied. Bribery scandals discredited several of its key leaders. And the economy -- after booming for years -- spiralled into recession.

Within this crisis, old enemies within the party decided to settle scores. Ichiro Ozawa, once a leading Prime Minister candidate, engineered a no-confidence vote, quit the LDP, and created a new party around his faction. In the ensuing election, every member in his faction won re-election, but the LDP captured only a minority of seats. Several non-LDP parties then regrouped. They coalesced around Ozawa and renegadeLDP politician Morihiro Hosokawa, and threw the LDP out of power. Yet Hosokawa could not break free of Ozawa's influence, and the coalition that had thrust him into power soon unraveled. He himself governed only eight months, and his successor (another ex-LDP politician) lasted barely two.

Maneuvering through the chaos, the Socialists struck a deal with the LDP that catapulted their own leader, Tomiichi Murayama into the Prime Minister's office. It was their first return to power since Tetsu Katayama's short-lived Socialist government in 1947. It was a return that did not last. Like Hosokawa, Murayama suffered under behind-the-scenes control by experienced LDP politicians. He implemented little if any of the traditional Socialist agenda, and his party lost its credibility. In the 1996 election the LDP regained sole control of the government. Usually in coalition with smaller parties, it has held the Cabinet ever since. ${ }^{13}$

2. The potential for change. -- Although the LDP eventually returned to power, it now faced a far more uncertain future. In the days before 1993, LDP leaders had faced an opposition fractured into several parties -- most of which lay far to the left of the median voter. Their loss in that year was due to Ozawa's defection, not to the power of

\footnotetext{
${ }^{12}$ We obtained the YJL roster from Shiso undo kenkyu sho, ed., Osorubeki saiban [Fearsome Trials] (Tokyo: Zenbo sha, 1969).

${ }^{13}$ For a description of the events of 1993, see, e.g., Jacob M. Schlesinger, Shadow Shoguns: The Rise and Fall of Japan's Postwar Political Machine (Stanford: Stanford University Press, 1997); Gary Cox and Frances McCall Rosenbluth, The Anatomy of a Split: The Liberal Democrats of Japan, 14 Electoral Studies 355 (1995).
} 
the traditional opposition. After 1996, they faced parties posing a much more serious electoral threat, and they would not regain an absolute majority in Parliament until 2005. In turn, this forced them to share power with coalition partners, albeit partners small enough not to threaten their dominance within the coalitions.

We closed our previous studies of judicial incentives before the 1993 crisis. During its four decades in power, we concluded, the LDP had stacked the Supreme Court with men who shared its policy preferences. These men had supervised the Secretariat, and the Secretariat had run a "tight ship." Under its control, the courts had operated as a smoothly running, hierarchically structured, and internally competitive organization. Competing for a finite set of career rewards within this internal labor market, court employees (i.e., judges) had worked hard and worked well. Largely, they had adjudicated disputes (a) predictably, (b) expeditiously, and (c) in politically sensitive cases, according to the policy preferences of the LDP.

At the time we began our work on the Japanese courts, too few years had elapsed since 1993 for us to measure any change. Now, however, the LDP has been back in power nearly a decade. How might the courts have changed? From 1993 to 1994, a coalition dominated by former-LDP politicians ran the Cabinet, with but dubious hopes of long-term survival. From 1994 to 1996, a bizarre coalition of the biggest parties of the left and the right controlled the Cabinet. Since 1996, the LDP has returned to power -but to an obviously fragile power.

These vicissitudes potentially affected the courts along several dimensions. First, where a capitalist party had ruled for decades, now a self-consciously leftist party briefly shared that control. All else held equal, we would expect more leftist personnel decisions. If a liberal Prime Minister replaces a conservative Prime Minister, we would expect him to appoint more liberal justices to the Supreme Court. Over time, we might expect the new justices to promote more liberal judges in the lower courts.

Second, where one party had ruled before 1993, from 1993 to 1996 coalitions ran the country. The presence of coalition governments muddies the potential influence of ideology. The Socialist Murayama may have wanted to shift the courts toward the left, but he shared power with the LDP and the LDP held no such preferences. Unfortunately for the empiricist, whether the government would now change the direction of the courts depended on the deals the politicians cut, but politicians disclose few such deals.

Finally, where the ruling party had expected to continue in power indefinitely before 1993, after 1993 no coalition or single-party government had such a high degree of confidence. We will next discuss why this matters.

3. The importance of expected tenure. -- (a) The desire to control. The politicians running Japan since 1993 have lacked any assurance that they can keep power indefinitely. In turn, those fragile prospects have potentially affected both their desire to control the courts and their ability to do so. Politicians stay in power by delivering portfolios of policies and programs desired by at least a plurality of voters. To do so, they need agents who will loyally design and implement the policies and programs those constituents demand. Within the executive branch, they appoint bureaucrats to the job. Within the judicial branch, they would like to have judges do the same.

Politicians need judges who will loyally interpret and enforce the policies and programs promised to voters. Voters do not elect them to appoint judges who do no 
work. Neither do they elect them to appoint judges who adjudicate cases without rhyme or reason, who take bribes, ${ }^{14}$ or who sabotage the very policies and programs for which the politicians were elected.

To be sure, some voters also have a "taste" for independent courts, though their ideal is perhaps independent judges who do just as the voters want. Yet independent judges can by definition do as they please. They need not follow precedent. They can invalidate programs they do not like. They need not even work hard. Even voters with a taste for an independent judiciary will not pay an unlimited price for it.

Politicians and voters do benefit from independent judges, but they benefit when their party is out of power. When their rivals control the government, they gain from institutions that block their rivals' ability to deliver the agenda the majority of voters -but, alas, not their people -- want. Independent judges offer precisely that obstacle. Indeed, by strategically interpreting statutes and constitutions, they may even implement the policies and programs of the out-of-power politicians. Politicians who anticipate losing power will not necessarily keep courts independent. Even they may decide that the gains to current control outweigh any benefit from extending their influence into future years. But where a party with high odds of staying in office has less incentive to keep courts independent, at least a party facing low reelection probabilities might choose to insulate judges from itself.

Moreover, according to a theory made famous by William Landes and Richard Posner, even majority politicians and voters might benefit from independent judges if they would otherwise be unable to keep their commitments. ${ }^{15}$ Suppose, for example, that voters want to encourage pharmaceutical companies to develop new drugs. To do so, they need to commit to honoring the patents they award rather than invalidating them after seeing the high prices the companies charge. Independent judges help overcome this temptation to renege. If the politicians care enough about the future, they thus may want to maintain the independence of those judges who remind them of their commitments. Through such independent judges, in short, they may preserve a reputation that makes their commitments valuable.

(b) The ability to control. A party's ability to stay in power also affects its ability to control the courts. Most straightforwardly, a party that anticipates staying in power can afford to appoint a 64-year-old justice when the retirement age is 70. Because the justice faces only six years in office, he will not significantly "grow in office" and change his political preferences. Because the party will still be in office when he retires, it will be able to replace him with another "sound" appointee.

Less obviously, a party with long-term prospects will also be better able to control the lower courts. Rational lower-court judges will know that the party will probably stay in office for the foreseeable future. As a result, they will not expect the political criteria for promotion to change over time. They will not reason that a boldly anti-LDP decision will, after an unhappy but short exile to Tottori, earn them a High Court seat when the Left comes to power. Not only will judges working under a party with long-term

\footnotetext{
${ }^{14}$ By "judicial independence," we refer to independence from the government, not independence from private parties in a case. We know of no one who would justify judges who take bribes from private parties.

${ }^{15}$ William A. Landes \& Richard A. Posner, The Independent Judiary in an Interest-Group Perspective, 18 J. Law \& Econ. 875 (1975).
} 
prospects more readily conform, heterodox jurists will tend to self-select out of judicial careers. If they share the political preferences of the opposition, they will instead opt for careers in politics, at universities, or in private practice.

4. Observable implications. -- What, then, might be the observable implications of the crisis of 1993? Might Hosokawa and Murayama have tried to shift the courts to the left? Might they and the LDP prime ministers who followed them have tried to weaken the ability of sitting cabinets to control the courts? If they tried either approach, we would expect to observe:

(i) Younger Supreme Court justices. Because the pre-1993 LDP could expect to stay in power, it appointed justices near enough to retirement not to change their politics while on the bench. If post-1993 politicians decided to extend their influence into the future, they would have appointed younger justices.

(ii) More justices from the universities and the bar. During the long years of LDP control, conservatives and the apolitical disproportionately self-selected into the bureaucracy and the courts. Those with tastes to the left instead opted for careers in the bar, in business, in politics, and in the universities. As a result, non-LDP Prime Ministers who wanted to control the courts would disproportionately have named justices from outside the bureaucracy and the courts.

(iii) Changed career patterns within the lower courts. Before 1993, the Secretariat ran the courts tightly, and used that control to favor judges who implemented LDP preferences in sensitive cases. If post-1993 politicians hoped to use it to implement different policies, they should have promoted different judges. If they hoped instead to reduce a ruling party's ability to manage the courts, they should have weakened Secretariat control more generally. In either case, the courts should exhibit large-scale deviations from earlier career patterns.

\section{Judicial Administration Since 1993:}

1. Introduction. -- We divide the period after 1993 into two parts: the interregnum of weak coalition governments from 1993 to 1996, and the LDP cabinets from 1996 to the present. We also divide the courts into two parts: the Supreme Court, subject to quick turnover after 1993 because of the proximity of all the justices to retirement, and the lower courts, where judges continued on their slow path to advancement under the supervision of the Secretariat. The direct impact of any changes would show up in the Supreme Court. The indirect impact would show up in the lower courts, either at once (out of anticipation of weaker control by a less pro-LDP Chief Justice in the future) or more slowly (once a new Chief Justice began supervising the Secretariat). 
2. Supreme Court appointees. -- (a) Age. Because they expect to lose power periodically, political parties in the United States name relatively young justices to the Supreme Court. So too did the Socialist Katayama in Japan in the 1940's. As Prime Minister when the new constitution took effect in 1947, he had the chance to appoint all fifteen Supreme Court justices. Just as one might expect from an American President, he appointed a majority of justices under age 60 .

By contrast, before 1993 the LDP could expect to stay in power indefinitely, and had little reason to appoint justices who were young. LDP leaders could afford to appoint the best-qualified candidates, regardless of age. Indeed, older candidates presented a distinct advantage. Younger justices can change over time and eventually enforce political preferences quite different from those of the party that appointed them. Rather than risk ideological drift, the LDP coupled mandatory retirement (at 70) with older appointees -- generally about age 64 (Table 1).

After 1993, prime ministers continued to appoint Supreme Court justices at about age 64. Nominally independent Hosokawa appointed his four justices at an average age of 64.8. At-least-nominally-Socialist Murayama appointed his five at a mean 62.6. Since returning to power, the LDP has kept the appointment age largely unchanged (Table 2).

(b) Careers. If by virtue of its unbroken power the LDP had shaped the courts in its image, men like Hosokawa and Murayama might have made a break from the past, and picked their justices from sources other than the courts that the LDP had controlled for so many years. Table 1 superficially suggests such a break from the past. Earlier LDP prime ministers had appointed over 40 percent of their justices from the judiciary. Hosokawa and Murayama each chose only one of their justices from the courts, and -significantly -- the man Murayama picked had been a member of the leftist YJL in the 1960s. ${ }^{16}$

Curiously, however, Hosokawa and Murayama did not turn to the obvious sources for the rest. They could have found plenty of independents and Socialists in the bar and the universities. Yet Hosokawa picked only one of his four justices from the bar, and Murayama picked only two. Neither chose a law professor. Instead, Hosokawa picked one justice from the Ministry of Justice (a prosecutor) and one from the Ministry of Labor, and Murayama picked one from the Ministry of Justice (another prosecutor) and one from the diplomatic corps. ${ }^{17}$

The appearance of a break with the past is deceptive. Neither Hosokawa nor Murayama controlled the Cabinet long, and neither controlled it without coalition partners. Rather than try hard to reshape the courts, they apparently retained the LDP

\footnotetext{
${ }^{16}$ Masao Fujii. That YJL members tended to suffer in their careers does not mean they all suffered. Fujii enjoyed a stellar career long before Murayama named him to the Supreme Court. Fujii joined the courts in 1957 at age 24. By the time of the YJL controversy in 1969, he was already in his teaching second stint at the LRTI. From there, he would go the Osaka District Court, the Osaka High Court, the Ministry of Justice Civil Affairs Bureau, the Tokyo District Court, and the Tokyo High Court. In fact, he became Chief Judge of the Osaka High Court (probably the third most prestigious post in the lower courts after the Secretary General of the Secretariat and the Chief Judge of the Tokyo High Court) 3 months before Murayama took office. Note that Fujii -- unlike some YJL members -- did promptly resign his membership in the organization when the controversy erupted in 1969.

${ }^{17}$ Obviously, the LDP would have exercised at least as much control over the executive branch as over the courts. Japan has a civil service system, but, as with the judges, tasks must be assigned and promotions granted, and the elected official at the top of the ministry will choose civil service heads who have done a good job of managing their subordinates.
} 
practice of "reserving" each Supreme Court seat for a particular "line." Under this practice, LDP Prime Ministers had replaced justices from the lower courts with lower court judges, former prosecutors with prosecutors, former lawyers with lawyers, and others with -- well, "others."

Appointed from the Fukuoka High Court in 1973, Justice Eriguchi illustrates one of the "judge" lines. When he retired in 1980, the Prime Minister replaced him with Justice Terada of the Tokyo High Court. Terada retired in 1985, and the Prime Minister replaced him with Justice Oouchi, again from the Tokyo High Court. In 1992, he was replaced by Justice Miyoshi (Tokyo High Court), and he in turn by Justice Kanaya (Tokyo High Court) in 1997.

By contrast, Justice Amano, appointed in 1971, had been a Osaka prosecutor. Within two days of his retirement in 1978, the Prime Minister named Justice Yokoi of the Nagoya prosecutors' office. Yokoi retired in 1984, and was replaced by Justice Nagashima of the same office. Four years later, he was succeeded by Justice Teika. Because Justice Teika had been a lower-court judge, the Amano-Yokoi-Nagashima line now became a judicial line. When Prime Minister Takeshita appointed the next justice three months later, however, he named a man from the Tokyo prosecutor's office. The LDP maintained similar "lines" for lawyers, and others for such assorted figures as professors, diplomats and bureaucrats. Hosokawa and Murayama adhered to the custom too, apparently deciding that judicial reform was not a high priority for their coalition governments.

3. The lower courts. -- (a) Introduction. To see what happened in the lower courts, we combine the methodology of our earlier studies with new data on the post1993 era. In these earlier studies, we examined three categories of variables that determined judicial careers: rulings in individual cases that might interest the LDP, membership in a leftwing political organization, the YJL, and nonpolitical variables such as quality of college degree and the number of times a judge failed the LRTI entrance examination. ${ }^{18}$ In this study, we focus on the last two categories. ${ }^{19}$

(b) Appointees. -- Since 1993, the Secretariat has continued to appoint annually about the same number of new judges it appointed earlier. Over the years, that number has fluctuated between roughly 70 and 110. The 94 new judges of 1998 fit into that range comfortably (Table 3, Pan. A). Although the 1998 judges on average did pass the LRTI exam more quickly than their predecessors, that shift just reflects a slight shift in the score necessary to pass the exam and not necessarily any change in the quality of the

\footnotetext{
${ }^{18}$ We estimate this from the age at which a judge entered the LRTI.

${ }^{19}$ As noted earlier, we take the data on judicial careers from Nihon minshu, supra note xxx, the data on YJL membership from Shiso undo, supra note xxx, and university affiliation for the class of 1998 from the Gakushikai, Kaiinshi meiroku: Heisei 10 nen yo [Membership Roster: For 1998 Use] (Tokyo: Gakushikai, 1997).

For the regressions below, we augmented the data by adding 17 judges from the classes of 1957 and 1959 to the class of 1958 and 24 judges from the classes of 1966 and 1967 to the class of 1968, to increase the number of YJL members in the sample. This is an example of "stratified sampling", a technique commonly used in statistics to increase the information content of the data.
} 
test-takers. Where the pass rate had stayed below 2 percent from 1974 to 1984, by 1996 (the year the Class of 1998 entered the LRTI) it had risen to $2.9 .^{20}$

The Secretariat did appoint more women in 1998 than in the past. Where in earlier years it had taken one woman for every nine men, by 1998 it accepted one woman for every four. Rather than any shift in Secretariat policy, however, the change probably reflects the larger number of women pursuing legal careers (by 2004, 23.5 percent of the LRTI class were women). ${ }^{21}$

(c) Initial postings. For many years, the Secretariat has identified its most promising recruits and named them to the TDC. In 1968, 33 percent of the Tokyo graduates and 55 percent of the Kyoto graduates started at the TDC, but only 7 percent of the others. And in 1978 the Secretariat named 31 percent of the Tokyo and 27 percent of the Kyoto graduates to the court, but only 15 percent of the rest.

At the same time, the Secretariat sent its least promising young judges to the branch offices and summary courts. In 1968 and 1978, only 1.5\% of Tokyo and Kyoto graduates started in a branch office or summary court; $9.1 \%$ of the graduates of other colleges did. Only 2.4 percent of the judges who flunked the LRTI exam 4 or fewer times started at such courts; 23.3 percent of the rest did. But by 1988, the Secretariat had abandoned its policy of starting any judges at branch offices, perhaps having decided that the weaker judges had all the more need to learn their trade from numerous and able senior colleagues.

The simplest way to compare career paths before and after 1993 is to look one by one at the various characteristics of LRTI graduates and see how a given characteristic relates to success. That is what Panel A of Table 4 does. The "pre-1993" column looks at the first assignments of judges from the classes of 1958, 1968, 1978, and 1988. The "post-1993" column looks at the first assignments of judges from the class of 1998. The first row tells us that 30 percent of the U. Tokyo graduates started at the TDC before 1993, but 63 percent did thereafter. The second row tells us that after 1993 more non-UTokyo graduates started at the TDC too, but that the increase was smaller. Apparently, when the Secretariat decided to increase the number of judges it started at the TDC, it looked primarily to its Tokyo alumni for the additional appointees.

Judges who flunked the LRTI exam fewer times also had a greater chance of starting in TDC $(24 \%$ if he flunked 4 or fewer times; $10 \%$ if he flunked more than 4 times), but after 1993 more judges started in Tokyo whether they had flunked the test seldom or often. A greater fraction of men than women started in TDC, and here too the fraction of both increased over time.

[Add Table 4 about here.]

Looking thus at probabilities characteristic-by-characteristic is a good way to start, but it has two deficiencies. First, it is hard to know quite what to make of a given cluster of 4 numbers -- male versus female, pre-1993 versus post-1993. When the percentage of both male and female judges starting in Tokyo rises, for example, what are we to make of any change in the effect of being male? Formal statistical tests exist to

\footnotetext{
${ }^{20}$ See the Ministry of Justice statistics at http://www.moj.go.jp/PRESS/051007-1/17syutu-gou2.html (last checked, Oct. 24, 2005).

${ }^{21}$ See the Ministry of Justice statistics at http://www.moj.go.jp/PRESS/051007-1/17ron-soukatu.html (last checked, Oct. 24, 2005).
} 
answer that question, but they cannot address the second deficiency: when different characteristics are correlated with each other, independent comparisons cannot tell us which is the true cause of starting in Tokyo. If U. Tokyo graduates also are less likely to have failed the LRTI exam many times, ${ }^{22}$ for example, both characteristics may seem to result in a higher chance of being posted to TDC, even if only one is truly causal.

The regression method used in Panel B of Table 4 solves these problems. Statistical regressions separate the effects of correlated potential causes, and generate measures of the reliability of the different effects. Table 4 uses a probit regression, the kind appropriate when the dependent variable that we are trying to predict (in this case, whether the Secretariat first posts a judge to the TDC) can only take two values -- here 1 if he starts at the TDC and 0 otherwise. We take as our data set information on all judges hired in 1958, 1968, 1978, 1988, and 1998. We then explore the impact on this posting of a judge's university affiliation (two variables equal to 1 if a judge attended either of the top two universities), the number of times he or she failed the LRTI entrance examination (Flunks), and his or her sex $($ Male $=1$ ).

To explore whether the class starting in 1998 differs significantly from the other classes, we interact these variables with (i.e., multiply these variables by) a dummy variable (Cl-98) equal to 1 if a judge is a member of the 1998 class and 0 otherwise. Thus, for a judge from the class of 1968 whose value of Flunks was 6, his value of Cl-98 * Flunks would be $0 * 6=0$. The non-interacted variables give us the impact of the variable on an initial TDC posting for the population as a whole. The interacted variables tell us whether the Secretariat treated the 1998 class differently from the others.

The positive number of .117 on University of Tokyo affiliation indicates that judges who attended Tokyo were more likely than the others to start at the TDC. The zstatistic of 1.91 indicates that the coefficient is greater than 0 at nearly the 5 percent significance level, giving us a moderate level of assurance that the effect did not result from coincidence. The marginal effect of .117 indicates that a Tokyo graduate is about 12 percent more likely than others to obtain this posting.

Similarly, the marginal effect of -.03 on Flunks indicates that each year a judge flunks the LRTI reduces his chances of starting at the TDC by 3 percent. This effect is highly significant, at better than the 1 percent level. The coefficients on sex and University of Kyoto affiliation, however, are not significant. Thus, the smaller percentage of women relative to men starting at TDC that we saw in Panel A is not big enough, given the small starting number of female judges, for us to conclude that sex actually mattered to initial appointment.

The interaction variables indicate that the Secretariat continues to favor Tokyo graduates and those who pass the LRTI exam quickly. The coefficient on the interacted Tokyo variable is positive, and that on the interacted Flunk variable is negative -- but the z-statistics are 1.48 and 1.73. Those z-statistics are too low for us to conclude that the Secretariat favors such judges more strongly as before, but neither does it seem that they favored them less strongly.

Note that the coefficient on the interacted sex variable is positive and significant at the 10 percent level: the data do not tell us whether the Secretariat favored men earlier (when there were few women), but by 1998 (when women were 19 percent of the group)

\footnotetext{
${ }^{22}$ For our database as a whole, U. Tokyo graduates flunked the LRTI a mean 3.21 times, U. Kyoto graduates flunked it a mean 2.95 times, and the other judges flunked it a mean 4.51 times.
} 
it significantly raised its preference for men over women. This illustrates the value of the regression technique. Panel A of Table 4 indicates that the percentage of women starting in TDC rose from 9\% pre-1993 to 24\% post-1993, a much bigger increase than for men, and to a much higher level. The regression, however, tells us that it is only after 1993 that we can reliably conclude that the Secretariat gave men a better initial posting than women.

Thus, we can conclude that the Secretariat did not greatly change the way it allocated its initial appointments after 1993. We do find that the number of women increased enough for us to conclude that it appointed women less often to the TDC. Obviously, this hardly shows any decreased conservatism.

(d) Methodological observations. We will apply the method just described -- first look at averages, characteristic by characteristic, then at regressions -- to various stages of a judge's career. In each case we will compare the impact of different characteristics before and after 1993, using regressions with interacted variables. For the first appointment in a judge's career, the post-1993 sample was the class of 1998. For judges 5-15 years out it will be the class of 1988, for those 15-25 years out the class of 1978, and for those 25-35 years out the class of 1968 .

Two variables we will use in the remainder of the regressions do not appear in Table 4. Leftist judges created a massive controversy in 1969 when a conservative group published the YJL membership roster. Because they had stayed out of the public eye until then, their membership did not affect the starting posts of the class of 1968 . Because of the controversy that ensued, judges of later classes did not join the League. ${ }^{23}$ For these reasons, we exclude YJL membership in Table 4. Because no members of the 1998 class attended the University of Kyoto (we do not know why the courts recruit fewer judges from the University of Kyoto than in the past), we also excluded an interacted Kyoto variable.

In the regressions to follow, we will use the "tobit" technique instead of "probit." Probit is appropriate when the dependent variable (TDC) can take only two values. Tobit is appropriate when the dependent variable (the percentage of a decade in a particular kind of post) cannot be less than 0 or greater than 100 .

(e) Early intermediate career (years 5-15) postings. Administrative jobs. After starting its top recruits at the TDC, the Secretariat continues to favor them through the early intermediate years (years 5-15) of their careers. Take its decisions about whom to name to prestigious administrative posts (Table 5, Panel A). ${ }^{24}$ Both before and after 1993, judges who started in the TDC, who were graduates of Tokyo University, and who were male spent more years in the prestigious administrative posts. Most dramatically, those who started at the TDC spent $28 \%$ of their decade 5-15 in administrative posts, compared to a mere $6 \%$ for other judges.

[Insert Table 5 about here.]

\footnotetext{
${ }^{23}$ So we have been told. As our YJL roster dates from 1969, it obviously would not list any judges who joined after that date.

${ }^{24}$ E.g., as an instructor at the LRTI, at the Secretariat, or at the Ministry of Justice. A judge with "sokatsu" responsibilities is not included, on the ground that such a judge will still be spending most of his time judging cases.
} 
Panel $\mathrm{C}$ of Table 5 uses regression analysis to explore which variables are truly significant determinants of administrative postings, and whether their importance changed over time. The dependent variable is thus the fraction of the decade covering the $5^{\text {th }}$ to $15^{\text {th }}$ years of a judge's career that a judge spent in administrative posts. As independent variables, we include the variables in Table 4, along with a dummy equal to 1 if the judge had been a member of the YJL in 1969, and a dummy equal to 1 if he started his career at the TDC.

Because judges in the class of 1988 were at years 5-15 during 1993-2003, we also interact all variables with class of 1988 affiliation. As in Table 4, these interacted variables let us test formally whether the Secretariat treated judges at this career stage differently during 1993-2003 than it had treated preceding "generations." Because no class of 1988 member joined the YJL, we omit the interacted term of that variable.

During the three decades from 1973 to 2003, the Secretariat significantly favored its TDC starters over their colleagues. The marginal effect of .19 indicates that such judges spent nearly two extra years of the decade with administrative responsibilities. The effect is statistically significant at better than the 1 percent level.

The Secretariat also favored men at this early intermediate stage of their career. This effect is also significant at the 1 percent level. The impact of YJL membership is not statistically significant, consistent with YJL members spending $10 \%$ of the decade and non-members $9 \%$ of the decade in administrative posts (Panel C). University affiliation and Flunks are also not statistically significant. This is less surprising than it might seem, because these variables do increase the chance of starting at the TDC (Table 4). Given the impact of the initial TDC appointment, Flunks and university affilation do indirectly affect the 5-15 decade performance.

The interaction variables again indicate that little has changed since 1993. The Secretariat now significantly favors Kyoto graduates more than it did before. The most interesting change is that failing the LRTI exam fewer times, a characteristic of little direct importance to this part of a judge's career before 1993, does have a noticeable, if small, effect afterwards. A judge who flunked the LRTI exam one more time than the median judge spends $1.2 \%$ less of the decade in an administrative post. The low significance levels on the other interacted variables show that the Secretariat has otherwise simply continued its practices from the past.

Branch offices. Panel B suggests that many of the same variables affect the fraction of the decade a judge spends in branch offices or summary courts (albeit in the opposite direction). Before 1993, judges who started at the TDC, who graduated from either the U. Tokyo or the U. Kyoto, who failed the LRTI exam fewer times, and who avoided the YJL spent less time in these undesirable posts. Curiously, it also indicates that women spent less time there than men. Other than the favoritism toward elite college students, it further suggests that these phenomena continued after 1993.

Because simple summary statistics are only suggestive, however, let us turn to the regression results in Panel D. This panel shows the result of a regression of the percentage of the 5-15 decade spent in branch offices or summary courts. For these jobs, YJL membership is significant -- a YJL member spent 1 more year in a branch office on average (the median judge in the classes of 58, 68, or 78 spent 3 years in branch offices during the 5-15 decade). Having flunked the LRTI exam more times is a highly 
significant predictor of branch office posting, and a first posting in TDC is a significant negative predictor. The effect of the university variables, however, is insignificant. Interestingly enough, men did indeed spend more time in branch offices than women (14.2\% more).

The interaction variables show two changes after 1993. First, Kyoto graduates did not go to branch offices (recall that they also took administrative jobs more often; Panel D). Second, the effect of being male disappeared. The marginal effect of -.106 for class of 1988 males effectively neutralizes the marginal effect of .142 for males generally. Otherwise, the Secretariat largely continued its earlier practices.

(f) Later intermediate career (years 15-25) postings. Administrative jobs. In this phase of his career a judge will usually spend much more time in administrative posts than before. Panel A of Table 6 shows that pre-1993 judges who started in the TDC spent a full $61 \%$ of the decade between their $15^{\text {th }}$ and $25^{\text {th }}$ years in administrative posts, and the figure was as high as $32 \%$ even for the other judges. The averages in Panel A show few changes from before 1993 to after, except that women seem to do much worse after 1993.

The regression results, however, show that the Secretariat did not change its treatment of women after 1993 (Panel C). Instead, other things held equal, women spent less time in administrative posts even before 1993 (two years less of the decade). That phenomenon did not thereafter change. Attending the University of Tokyo or Kyoto and starting one's career in the TDC helped one's career. Being a member of the YJL significantly hurt it. For this phase of a judge's career, nothing changed after 1993: every one of the interaction variables is statistically insignificant.

[Insert Table 6 about here.]

Branch offices. Oddly enough, being a YJL member seems not to have affected whether a judge spent time in a branch office during his later intermediate career. What did matter was (as with obtaining administrative jobs) whether he graduated from the Universities of Tokyo or Kyoto and spent his first years at the TDC (Panel B). Where a non-YJL judge spent 18 percent of the decade in branch offices, the YJL member spent only 3 percent more. But where U. Tokyo graduates spent 11 percent, the others spent twice as much time there. Where the U. Kyoto graduates spent 7 percent, the others spent three times as much. Those who started at the TDC spent 8 percent of the decade in branch offices, while the rest spent 21 percent. And those who failed the LRTI exam fewer times spent fewer years in branch offices.

The regressions (Panel D) confirm the insignificance of YJL membership on branch office postings at this stage of a judge's career. They also confirm both that elite university graduates spent less time in branch offices before 1993, and that the Secretariat did not significantly change that policy thereafter. They indicate that the Secretariat favored TDC starters both before and after 1993, that any preference for low-Flunk judges appeared significant only after 1993, and that the effect of sex was insignificant.

(g) Late career (years 25-35) postings. Administrative jobs. The last phase of a judge's career is especially interesting for us because the years after 1993 cover the class of 1968, the last class to contain YJL members. Judges in later classes have not yet 
reached this stage of their careers. As a result, we here compare the class of 1958's late career (from 1983 to 1993) with the class of 1968's (from 1993 to 2003).

Panel A of Table 7 shows that before 1993, most of our judge characteristics hardly matter to administrative appointments. Judges who started in the TDC did no better than those who did not; in this context at least, the effect of a good start seems finally to have worn off 25 years after graduation. The effect of youthful indiscretion has not, however. The one characteristic that shows a substantial impact on administrative appointments is YJL membership: those who had joined the group decades earlier were still spending 19\% less time in administrative jobs (Panel C).

[Insert Table 7 about here.]

The penalty on YJL membership continues post-1993, and the other variables start showing an effect too: at least by the simple averages of Panel A, after 1993 judges who started at the TDC did better than those who did not; Universities of Tokyo and Kyoto graduates did better than the others; and those who passed the LRTI exam quickly did better than those who failed repeatedly. Has the Crisis of 1993 at last produced a change in judicial careers, for those judges senior enough to be in positions of power?

The regression results say no: in fact, very little has changed (Panel C). YJL membership continues to have a negative effect. The effect is significant, subtracting 1.75 years from a judge's time in administrative jobs. Crucially, the small and insignificant marginal effect of .028 for the interaction variable shows that the adverse effect of YJL membership persists after 1993. Neither the brief stint under a Socialist Prime Minister nor the LDP's loss of its long-term lock on power helped judges who had shown their leftwing leanings 25 years before. We cannot say whether this was because of their actual membership, or just because of the beliefs that induced them to become members, but in either case, the actively leftist young judges were doing worse than other judges in their late careers.

The other variables show little effect on administrative postings. Although men seem to have done better than women before 1993, the absence of more than two women in the 1958 class makes the calculated coefficient unreliable. All other calculated effects are insignificant before 1993. Only being a Kyoto graduate had a significant effect afterwards.

Branch offices. Time spent in branch offices in a judge's late career tells a similar story, with two differences (Panels B and D). First, although none of our judge characteristics predicts branch office time significantly before 1993, after 1993 TDC start does. Having begun one's career at the TDC does reduce the amount of time a judge spends in branch offices 25 years later. Apparently, the "good start" effect does persist here, even if not with administrative jobs. Second, YJL is as unimportant as the other variables in predicting branch office time. YJL membership seems to have reduced the rewards to a judge, but not increased the penalties.

(h) Summary. This has been a bewildering number of regressions, but they let us explore whether anything has happened during the 1990's to any of the phases of a Japanese judge's career. Several conclusions emerge. First, merit -- at least as measured by the quality of a judge's college, his first assignment, or the number of times he failed the LRTI exam -- has not diminished in importance. In some contexts (e.g. branch office 
assignments in mid to late career) these meritocratic variables have become even more important than they were before 1993. Second, men now do better than women. Paradoxically, however, that phenomenon may just reflect the fact that too few women joined the courts before the 1990's to measure the effect of sex with much confidence. Third, the adverse effects of YJL membership continued even into the 1990's, long after the events of 1968. Whether because of the continued stigma of membership or, more likely, because youthful membership can signal leftwing sympathies that last a lifetime, YJL judges suffered lagging careers even thirty years later.

Although the LDP lost its dominance in 1993, that loss did not reduce the career pressures, political or meritocratic, on lower court judges. Instead, the Secretariat continued to administer the courts much as it had done before. What was an earthquake in electoral politics left the judges with much the same incentives they had always had.

\section{The Case for Managed Judges}

What should we make of all this? Does the Japanese Constitution need a drastic overhaul? Did it (and we drafted it, after all) create this mess? Or is it even a mess?

\section{A. The Constraints:}

1. Japan. -- The Japanese Constitution did not generate this system. The Constitutions of Japan and the United States do not treat the courts very differently. In both, Supreme Court justices are appointed by the executive branch. They cannot be removed except by impeachment or, in Japan, through popular vote or upon reaching retirement age. Lower-court judges in Japan serve ten-year terms but, as we noted, the government almost always renews their terms. It cannot cut their pay, and neither can it discipline them except for gross misconduct. The court system is formally independent, and the Supreme Court has the last word on the law. All this is essentially the same in both countries.

What differs is the internal structure of the courts, which neither country's Constitution dictates. According to the constitutional text, Japanese politicians could reorganize the courts by statute and insulate them from even indirect political control. According to the text, American politicians could reorganize the federal courts and rein in judges who opposed their wishes.

Start with Japan. The only constitutional constraint on internal court structure appears in Article 80:

[J] udges of the inferior courts [shall] be appointed by the Cabinet from a list of persons nominated by the Supreme Court. All such judges shall hold office for a term of ten (10) years with privilege of reappointment, provided that they shall be retired upon the attainment of the age as fixed by law.

Article 80 does not mandate the system Japan now has. Granted, it does require the Cabinet to obtain the consent of the existing Supreme Court for its lower-court nominees, instead of the consent of the upper house, as in the United States. Yet giving the Court that veto increases the power of the courts rather than reducing it. The rest of Article 80 also need not be adverse to the power and independence of the judiciary. If the Japanese parliament wanted to give judges life tenure, it could change the statutory 
retirement age from 65 to 120 . If it wanted to end three-year rotations, it could mandate appointment to specific courts in specific regions. These are matters of statute and administrative practice, not constitution.

2. The United States. -- Perhaps more surprisingly, the U.S. constitutional text does not prevent the U.S. from having a system like Japan's. The Constitution does not mandate federal circuits. By statute, Congress could abolish them and empower the Chief Justice to decide the location and court at which each federal judge would work. It could allow the Chief Justice to run a personnel office that would preliminarily make that decision. And it could permit him to staff that office with the judges he finds brightest and most trustworthy, serving there at his pleasure. As in Japan, he could then transfer judges whose rulings displeased him to places the judges did not want to live.

Even under the existing statutory framework, a President with a loyal Chief Justice could use postings to punish a disagreeable judge. Suppose one President appointed prominent University of Chicago Professor I. Jones to the Seventh Circuit Court of Appeals in downtown Chicago, conveniently near his home. Four years later, suppose Jones started enjoining the successor President's legislation. The new President could not fire Jones or cut his pay (U.S. Const., art III sec. 1). Neither could he disregard Jones' injunctions (though he could appeal them). But if the Chief Justice agreed, he could find an overworked court that needed more judges. By 28 U.S.C. Sec. 291, he could then order Jones to show up "temporarily" for work in such courts. Pinch-hitting Jones might have to move from Omaha to Tallahassee to Anchorage and back again.

If the President (like the LDP) controlled the legislative branch, he could go further. Suppose he wanted to punish not just Jones but the entire Seventh Circuit. He could merge it into the adjoining Eighth (by 28 U.S.C. Sec. 48). He could then require the Chicago judges to rotate through St. Louis, Kansas City, Omaha, and St. Paul.

Does all this sound implausible? In fact, many of the statutes are already in place. About half of the judges sitting in U.S. federal district courts are in a special class of judges created by the Federal Magistrate's Act of 1968 who are appointed by other judges, serve eight-year terms, and can be fired for poor performance. ${ }^{25}$ The Administrative Office Act of 1939 created the circuit judicial councils, administrative bodies run by the judges. ${ }^{26}$ And the Judicial Councils Reform and Judicial Conduct and Disability Act of 1980 authorized the judicial councils to reprimand judges, to take away all their cases, or to certify them as disabled. ${ }^{27}$

Even reprimands, however, seem to be uncommon, even if misbehavior does occur. Geyh reports that "Instances of judicial misconduct included judges who appointed relatives as court officers or who heard cases litigated by relatives; judges who

25 Tim A. Baker, The Expanding Role of Magistrate Judges in the Federal Courts, 39 Val. U.L. Rev. 661,663 (2005).

${ }^{26}$ Administrative Office Act, $\S 305,53$ Stat. 1223 (1939).

27 "Action by the judicial council under paragraph $(1)(C)$ may include... ordering that, on a temporary basis for a time certain, no further cases be assigned to the judge ... censuring or reprimanding such judge... certifying disability of the judge ... requesting that the judge voluntarily retire..." 28 U.S.C. $\S 1,16, \S 354$ (2005). A judge certified as disabled can be replaced as if he had died, and descends into an uncertain status "junior in commission to the other judges of the circuit”, 28 U.S.C. $\S 1,17, \S 372$ (2005). From six to thirteen judges--- poor records are kept--were involuntarily certified as disabled as of 1993. Charles Gardner Geyh, Informal Methods of Judicial Discipline, 142 U. Pa. L. Rev. 243, 275 (1993). 
improperly refused to disqualify themselves; judges who were suspected of corruption; judges who billed the government for questionable expenses; and judges who were accused of being excessively aggressive in moving cases on their dockets. Instances of judicial inaction included both judges who delayed decision-making and judges who took extended vacations...". ${ }^{28}$ The leading case is Chandler v. Judicial Council of the Tenth Circuit, 398 U.S. 74 (1970). Chief Judge Chandler's “docket was backlogged, he had been named as a defendant in civil and criminal cases, and he had been issued writs of mandamus twice for failing to disqualify himself from hearing cases where he had an alleged bias toward one of the parties." 29 The Judicial Council ordered that he be given no new cases and his existing ones be taken away from him. He filed a motion with the Supreme Court, but the Court ducked the issue of constitutionality and rejected the motion on procedural grounds. Even here, however, the judge's punishment was merely embarrassing publicity and a reduction in his workload. American judges do not have significant power over other Article III judges, but that is a matter of statute and custom, not the Constitution.

The basis for the Japanese approach thus does not lie in the constitutional text. It lies in statute, and in the competitive internal labor market that statutes create. Given the electoral markets in which Japanese legislators must compete to survive, it lies in the preferences voters hold.

\section{B. The Alternating Parties Theory of Judicial Independence:}

If the texts of the constitutions do not dictate the different judicial systems, why then do the Japanese and U.S. courts operate so differently? In earlier work we proposed an alternating parties theory of judicial independence. ${ }^{30}$ Consider an incumbent political party that must decide whether to "manage" its judges or keep them "independent." Ignore for the present considerations of efficiency in everyday law (see Sec. D, below). Look instead at politically charged cases like election law and reapportionment disappointments.

In these charged cases, suppose the incumbent party prefers managed judges. We represent this preference in Table 8 with a payoff of 10 from managed judges and 8 from independent and unbiased ones. The opposition party prefers the independent and unbiased judges, which we represent by a payoff of 6 compared to 0 for managed judges. The particular numbers merely indicate the ordering of preferences rather than size, except for the following crucial point: the sum of the parties' payoffs is greater when judges are independent and unbiased. We postulate this because both parties value predictable decisions that follow the legal text, and unbiased decisions promote such qualities.

${ }^{28}$ Geyh, supra note, at 263, footnotes omitted. Geyh describes a sample of complaints and their results, as does Jeffrey N. Barr \& Thomas E. Willging, Decentralized Self-Regulation, Accountability, and Judicial Independence Under the Federal Judicial Conduct and Disability Act of 1980, 142 U. PA. L. REV. 25 (1993).

${ }^{29}$ Geyh, supra note, at 269.

${ }^{30}$ Ramseyer \& Rasmusen, supra note $\mathrm{xxx}$, chapter 7. Other recent examples of the theory include Tom Ginsburg, Judicial Review in New Democracies (Cambridge: Cambridge University Press, 2003), F. Andrew Hanssen, Is There a Politically Optimal Level of Judicial Independence?, 94 Am. Econ. Rev. 712 (2004), and Lee Epstein, Jack Knight and Olga Shvetsova, Selection Selection Systems, chapter 9 of Judicial Independence at the Crossroads, ed. Stephen Burbank and Barry Friedman (Thousand Oaks: Sage Publications, 2002). 
[Insert Table 8 about here.]

If the Table 8 parties play the game as a one-shot game, then the incumbent will choose managed judges regardless of whether that hurts his opponent more than it helps him. In the one-shot version, efficiency yields to self-interest. If the parties repeat the game indefinitely, however, matters potentially change. Suppose they hold an election every four years, and with each election the opposition party obtains a chance to become the new incumbent and itself use the judiciary selfishly. If the incumbent enjoys very high odds of winning the next election--more than a 3 in 4 chance, using our example's numbers--- nothing changes.

Matters do change if the opposition obtains a serious chance of winning the next election. Suppose the bias to the decisions by managed judges do not deny the opposition that chance. Two possible equilibria now emerge. First, each party may choose to manage the judges when it is in power, knowing that the other party will not later reward any forbearance with its own forbearance. This inefficient equilibrium will then become a self-fulfilling expectation. If each party has a $50 \%$ chance of winning an election, this will yield an average payoff of 5 to each party, 50\% times 10 plus $50 \%$ times 0 .

Second, each party may choose independent and unbiased judges while in power, in the belief that if it leaves the courts alone the other party will as well. This efficient equilibrium can also generate self-fulfilling beliefs. Each party's average payoff will now be 7 (50\% times 8 plus $50 \%$ times 6$)$,-- higher than the average payoff of 5 in the inefficient equilibrium. ${ }^{31}$

Turn now to the possibility of independent but biased judges: judges who feel free to decide cases against the incumbent, but who do so according to their own political preferences rather than the law. They would produce politicized law rather than efficient law -- to what, referring to the current Supreme Court, Richard Posner characterized as "essentially personal, subjective, and indeed arbitrary" opinions ${ }^{32}$-- but not necessarily law politicized to help the incumbent. Rather, the outcome will be random politicization. Whether the incumbent wins his election law case or not will depend on sheer luck. Because half of the decisions will favor each party and all outcomes will generate poor law, we assign expected payoffs of 5 to both the incumbent and the opposition. If the two parties expect to alternate in incumbency and opposition, they are indifferent between managed judges and independent judges, because both yield expected payoffs of 5. They would prefer independent unbiased judges, for expected payoffs of 7 each. On the other hand, if a party expects to be in power enough of the time, it would prefer managed judges -- with a payoff of 10 whenever it is in power -- to independent biased judges. Thus, a system of independent but biased judges is never optimal. We nevertheless raise the possibility to emphasize that judicial independence does not remove politicization from the judiciary and, in fact, can make things worse.

Consider now the United States and pre-1993 Japan. Competition for control of the federal executive branch of the United States is vigorous and the Democratic and

${ }^{31}$ If the payoffs are defined in terms of utility rather than money, as is standard in game theory, then Table 8 already incorporates risk aversion. The reason a player prefers the $8 / 6$ payoff combination to $10 / 0$ is not that although the payoff of 10 is the highest, the extra benefit to the incumbent from biased judges is less than the extra loss to the opposition. This is why average payoff from the independent but biased judges is worse than with independent judges, despite the $5 / 5$ payoff having less risk.

${ }^{32}$ Richard A. Posner, Foreword: A Political Court, 119 Harv. L. Rev. 31, 40 (2005). 
Republican parties alternate in power. Federal judges are independent, and -- when politically biased -- biased in both directions in ways that largely track the biases of the Presidents who appointed them. In Japan through 1993, on the other hand, the LDP was secure in power. As the incumbent party in Table 8, it preferred a system of managed judges, and that is the system that continued through its years in power.

\section{Japan after 1993:}

Why then did things not change in Japan after 1993? Once the LDP lost its traditional high probability of victory in every election, does not our alternating parties theory suggest that it would choose a more independent court system? Would it not expect that it could best promote its future interests if it disabled the Supreme Court and Secretariat from interfering with the careers of lower-court judges? After all, if it continued to maintain political and "managed" courts, its rivals would likely intervene equally politically whenever they came to power. Yet when the LDP returned to power, the age and background of the Supreme Court justices did not change. Neither did the career patterns in the lower courts.

The lack of change in the age and background of Supreme Court justices from 1993 to 1996 is easy to explain. The multi-party coalition of 1993 had "other fish to fry," and did not bother trying to renovate the court system it inherited. The LDP-Socialist coalition that followed was equally unstable and, locked in a coalition with the LDP, was not likely to change radically the system the LDP had designed. Murayama did not break with the tradition of appointing an elderly lower-court judge to a particular Supreme Court "line", though he did manage to find a YJL member who fit that description. After 1996, however, the LDP seems to have been equally unwilling to abandon its system of "managed" lower-court judges and its tradition of appointing Supreme Court justices close to retirement.

Perhaps the LDP - - and the pro-LDP holdovers on the Supreme Court -- wanted to change to the efficient equilibrium of independent and unbiased judges, but did not think they could change expectations. Remember, even with alternating parties, the inefficient equilibrium can continue as a set of self-fulfilling expectations; it is just that the alternation makes a more efficient equilibrium potentially self-fulfilling as well. Perhaps in 1996 the LDP thought that its successor would "manage" the courts politically no matter what strategy it chose.

Or maybe our Table 8 alternating parties theory does not really describe Japan. In the theory, we assume that the combined payoffs of the opposition and the government are higher when judges are independent. This could be false for at least three reasons.

First, the LDP did not need courts to be independent for people to trust it to honor the terms of its legislation. Through its long track record, by 1993 it had already built a solid reputation for keeping its promises. Landes and Posner suggested that politicians establish independent courts not because they fear what would happen in elections, but because no one would otherwise believe the promises they made their constituents. A government may establish a patent system, but inventors will not respond unless they think it will honor the patent later. By creating independent courts that force itself to honor the patents, it makes its promise to inventors credible. The logic applies to all government promises, from the promise not to take property without compensation, to the promise to pay contractors for road projects. 
The LDP, however, had less need for this kind of commitment mechanism. It had long been in power. Unlike a new party, it had a good track record for reliability in honoring deals, even if not for abstention from collecting the proceeds from such deals.

Second, in the Japanese system of "managed judges," the judiciary (even if not the judges) is independent. Although politicians choose Supreme Court justices in both the United States and Japan, in neither can they fire the justices. In an extreme constitutional crisis -- say, an executive who wants, Hitler-like, to grant himself dictatorial powers -- we could expect both Supreme Courts to behave similarly (whether similarly well or similarly badly is hard to say). The difference between the U.S. and Japanese judiciaries lies in the lower courts.

In the "managed judges" system of Japan, the lower-court judges lack independence. They are free of direct control by politicians, but the Supreme Court and Secretariat control their careers. Although the Secretariat must pick the judges from the small but talented pool of people who have passed a difficult examination and chosen a judicial career, it can punish and neutralize dissident judges without overruling each of their decisions. Japan can avoid the outcome of independent but biased judges relatively easily: the Secretariat selects judges for ability rather than interest in politics, and suppresses any lower-court judge who does develop a taste for making public policy. At the same time, if the Secretariat-following the wishes of the voters and the LDP--- does want the lower-court judges to make public policy intelligently, filling gaps left by statutes, it can reward judges for their policymaking ability. It is just that those policymaking judges may be punished if they choose policies of which the Secretariat disapproves. Obviously, this leaves little scope for the judge to indulge his personal political tastes.

In the United States, however, the President and Senate pick lower-court judges, and once picked those judges enjoy secure jobs. Although this enables the President to pick politically loyal judges, it reduces his (or the Supreme Court's) ability to control them. ${ }^{33}$ Thus, the Supreme Court of Japan has more power over the courts than the Supreme Court of the United States, even though it rarely overturns its statutes or injoins the government. ${ }^{34}$

Happy with such a system, perhaps the LDP decided that its best strategy in the new competitive environment was to establish as an equilibrium a self-perpetuating independent judiciary -- independent, but with conservative inclinations. Granted, if it shifted to appointing justices at age 50 it could reduce the ability of successors to appoint new justices. It would also, however, create a new tradition of radical change in the judiciary of which those successors might take full advantage. And it would give the 50year-old justice more years to change his conservative inclinations and decide that he liked making public policy. Regardless of whether he stayed conservative or shifted to the left, he would reduce the power of the executive and legislative branches. Better, the LDP perhaps reasoned, to continue its tradition of appointing old justices.

\footnotetext{
${ }^{33}$ As Posner, supra note, at 63, put it, "life tenure on a fixed salary ..., so that there are neither carrots nor sticks ... is a temptation to irresponsibility."

${ }^{34}$ Recall that the United States Supreme Court only invalidated two federal statutes in its first 70 years--- in Marbury v. Madison 5 U.S. 137 (1803) and Dred Scott v. Sandford, 60 U.S. (19 How.) 393 (1857) (William H. Rehnquist, Judicial Independence, 38 U. Rich. L. Rev. 579, 585 (2004). The Japanese Constitution of 1947 has only been with us 59 years.
} 
Third, the system of "managed judges" works. Independent but biased judges create a mish-mash of law attractive to neither the incumbent nor the opposition. They do so in everyday cases as well as electorally sensitive ones. "Managed judges" will be more consistent even than independent and unbiased judges, as we will explain in the next section.

\section{The Benefits:}

Managed judges yield dramatic benefit for Japanese citizens. The judges may favor the politics of their manager. But they also have a strong incentive to perform. By placing them within a competitive internal labor market, the Japanese government has given them strong incentives along two crucial dimensions: to work hard, and to decide similar cases similarly.

1. Rhetoric. -- If we miss the virtues of managed judges in the academy, we miss them because we assume that with judicial independence, more is better than less. A little common sense goes a long way here. Judges are government employees. They may have gold-plated educations. They may be smart. They may be sophisticated. They may even be rich, in comparison to postal workers. But they are still government employees. And like all government employees -- like all human beings -- they do more and better work if someone notices and rewards them for their efforts.

Unfortunately, in the rhetoric with which we describe all matters legal, we lose that simple truth. We speak of the legal "profession" rather than the legal services industry. We speak of "access to justice" rather than of helping people win their quarrels. To referee these quarrels, we hire (and pay from the public fisc) a specialized corps of government workers called judges. But at least in the federal courts, we neither supervise them nor give them incentives to work hard. Instead, we glorify their essential irresponsibility. As Henry Hart put it: ${ }^{35}$

[T] he Court is predestined in the long run not only by the thrilling tradition of Anglo-American law but also by the hard facts of its position in the structure of American institutions to be a voice of reason, charged with the creative function of discerning afresh and of articulating and developing impersonal and durable principles of constitutional law ....

As with the academic freedom for we professors, the judicial independence of judges is romantic and comfortable, but not the situation best suited to intense effort or strict accountability. Indeed, judges do not even have to worry about having their opinions rejected for publication. We would not therefore expect federal judges to operate as efficiently as, for instance, civil-service administrators in the Department of Agriculture, who must compete for promotion, even if they have little fear of unemployment.

2. Results. -- In Japan, politicians do not insulate their judges. Instead, judges who bring talent and energy to the job are rewarded. The (relatively) dull and lazy fail to advance.

${ }^{35}$ Henry M. Hart, Jr., Foreword: The Time Chart of the Justices, 73 Harv. L. Rev. 84, 99 (1959). The sentence is charcterized as "the famous purple passage" by Posner, supra note, at 72. 
The results are impressive. Where the federal and state governments in the U.S. employ 27,000 judges and magistrates, the Japanese government uses barely 3,000 regular and summary court judges. ${ }^{36}$ With half the American population, Japan makes do with one ninth the number of judges.

These many fewer judges process cases with the alacrity of many of our federal courts. Overall, federal district courts decide about 65 percent of their cases within a year, and 85 percent within two years. Japanese courts decide 55 percent within a year and 78 percent within two. That is slower than the federal courts on average, but close -and that puts them far ahead of many state court systems. ${ }^{37}$

Although the competitive labor market within the Japanese judiciary does induce judges to work hard and to work smart -- the Secretariat does look at case management as one skill they want to see in a judge - the key to the spectacular performance of the national system probably does not lie in judicial effort. We obviously speculate here, and turn to issues beyond the scope of our data. But the key to the success of the Japanese judiciary probably lies instead in uniformity -- particularly, in the uniformity of the judicial output. When monitoring and evaluating its employees (i.e., judges), the Secretariat does examine how hard they work. It apparently weighs docket-clearance rates heavily (we have long wished we had the data for our regressions). And that fact obviously affects how rapidly judges process cases. Yet the Secretariat also examines output quality. Do judges follow precedent? Do they decide cases the same way other judges have decided similar cases in the past? By requiring judges to decide like cases alike, this increases the predictability of the adjudicative process. In turn, that predictability promotes settlement. Whether in the U.S. or in Japan, litigation is expensive. As a result, anywhere in the world most disputants litigate a quarrel only if they cannot agree on the expected outcome of the litigation. More specifically, they litigate only if they each are optimistic about the outcome. ${ }^{38}$

Through its monitoring, the Secretariat reduces the variance in the adjudicative process. By reducing that variance, it reduces the fraction of disputes in which the parties both estimate their chances in litigation optimistically. And by reducing that incidence of mutual optimism, it increases the ability of parties to settle their dispute and pocket the fees they would otherwise pay their lawyers. ${ }^{39}$

3. Politics. -- The "costs" of these managed judges are far lower than most commentators claim. Although we often focus on political cases, as being the most interesting, very few cases raise political issues. Notwithstanding our use of terms like "justice," "fairness," and "equity," the vast majority of court cases in any modern society are mundane in the extreme: primarily, traffic accidents and debt collection disputes. In consensual transactions such as debt contracts, however, the expected litigated outcome

${ }^{36}$ U.S. Dept. of Labor, Occupational Outlook Handbook (On line, 2005).

${ }^{37}$ J. Mark Ramseyer \& Minoru Nakazato, Japanese Law: An Economic Approach 140-41 tab. 6.1 (Chicago: University of Chicago Press, 1999) (data for 1994).

${ }^{38}$ The point is well known, and stems from the early work, e.g., William M. Landes, An Economic Analysis of the Courts, 14 J. Law \& Econ. 61 (1971); Richard A. Posner, An Economic Approach to Legal Procedure and Judicial Administration, 2 J. Legal Stud. 399 (1973).

39 J. Mark Ramseyer \& Minoru Nakazato, The Rational Litigant: Settlement Amounts and Verdict Rates in Japan, 18 J. Legal Stud. 263 (1989). 
of a dispute necessarily generates offsetting ex ante adjustments to terms (inaccurate court assessments of expectation damages cause contracts to include liquidated damage terms, for example). As a result, even of these two categories of cases, only traffic accidents raise any serious issues of fairness.

What is more, even in those rare politically sensitive cases, a Japanese-style monitoring system will usually just induce judges to deliver the policies and programs that the electorate wants. In comparing countries like Japan and the U.S., politicians win office only through highly competitive electoral markets. Necessarily, those who do not deliver the portfolio of policies and programs demanded by a majority of the electorate do not stay in power. When those majority politicians enforce on judges their political "bias," they largely -- with exceptions to be sure -- merely force their judges to deliver the same. $^{40}$

\section{Conclusions}

In Japan, as in the United States, everybody loves judicial independence---as an abstract concept. That includes the Chief Justice and his colleagues. Were he to examine the concept a little more closely, however, even the U.S. Chief Justice's enthusiasm might wane. Does he really prefer having judges in the lower courts who are independent enough to flout his wishes without any consequence except the occasional reversal, a reversal that leaves a case's outcome no worse, in the judge's view, than if he had stayed subservient to the Supreme Court in the first place? Might the Chief Justice not prefer to be able to transfer a troublesome lower-court judge--in his view, an incompetent judge-- away from an appellate court or a big-city trial court to a divorce court in the hinterland?

To calm the Chief Justice' troubled conscience, we would point out that giving him the power to transfer a troublesome judge does not necessarily reduce the independence of the judiciary. It reduces the independence of individual lower-court judges, to be sure, but it is a transfer of power from one kind of judge to another, from the lower-court judges to the Chief Justice. The net effect would be to strengthen the judiciary as a branch of government, not to weaken it: unity strengthens an organization. Not only would the judiciary speak with one voice, but the lower court judges, if not the Chief Justice, would have stronger incentives to work harder, and the most important positions would go to the hardest-working and smartest judges. Actually, they would go only to the hardest-working and smartest judges of those willing to toe the line, but merit would nonetheless play a key role in selection.

\footnotetext{
${ }^{40}$ Commentators sometimes raise the need to protect "powerless" minorities. Yet if the majority party in the legislature will not protect them, we see little reason to think their appointees in court would do so either. Commentators routinely invoke the civil rights cases won by the African-American community. Most of these cases African-Americans won only after they became a key component of the coalition behind the Democratic Party. They did not win civil rights in court because they were politically powerless. They only began winning them after they ceased to be powerless. This thesis's best known advocate is Gerald Rosenberg, in his 1991 The Hollow Hope: Can Courts Bring About Social Change? (Chicago: Chicago University Press). A rejoinder is Paul Frymer, Acting when Elected Officials Won't: Federal Courts and Civil Rights Enforcement in U.S. Labor Unions 1935-85, 97 Am. Pol. Sci. Rev. 483 (2003), which argues that the courts desesegregated labor unions when elected officials failed to act. That article confirms, however, that court action only began to be effective after the late 1960's, when African-American political power had grown, and that attempts to give the EEOC more enforcement power were opposed not only by southern members of Congress, but by civil rights lawyers who preferred private enforcement.
} 
Japan has had such a judicial system, with much success. Despite its constraints, it has attracted some of the best and brightest of university graduates. Indeed, perhaps it attracts those graduates precisely because of its constraints. After all, the system clearly and predictably rewards merit among those judges willing to put aside their personal political preferences, and such rewards will attract many bright young minds. Nor need a Japanese judge spend the first half of his life cultivating connections with politicians so as to enhance his chances for appointment or election. All he must do -- but do throughout his career -- is to work hard and pay attention to what the Secretariat wants of him. The system may not, as a result, attract people who want to change the world, but it does attract those who are willing and able to implement the law uniformly across the country as the Supreme Court wishes.

One reason this system has worked well in Japan was the comfortable but not dictatorial dominance of the Liberal Democratic Party before 1993. With its long time horizon and ability to make law via legislative enactment rather than court rulings, the LDP was willing to control the courts with a light hand in most matters, with notable exceptions such as election law and injunctions, so long as the courts stayed out of politics. After 1993, Japanese politics became more like that of other democratic countries, with the incumbent party never very confident that it would win the next election.

In theory, the LDP's more tenuous hold on power might have led to Supreme Court justices appointed younger and serving longer terms. In theory, it might have led to lower-court judges more willing to buck the current Secretariat in the hopes that a future one might reward them. In practice, we have found no evidence of either phenomenon. Rather, we see the courts at all levels continuing much as they did before. Is this because the Liberal Democratic Party, which has continued to be in power for most of the years between 1993 and 2005 despite its shakier hold, likes the political viewpoint of the current judiciary and would not mind establishing a custom of leaving it as it has been in the past? Or is it that the conventional wisdom of LDP insecurity after 1993 is not shared by the LDP leaders, and they see their hold on power as stronger than we do. We will not pretend to know more about Japanese politics than the leaders of the LDP, but we have made our guess about what they believe; look back in ten years, readers, and tell us if we were right. 
Table 1: Appointments to the Supreme Court, 1973-2003: Selected Statistics

A. Justices appointed: $\quad 82$

B. Chief Justices appointed: $\quad 7$

C. Mean age of appointment of Justices -

$\begin{array}{ll}1973-1982: & 63.8 \\ 1983-1992: & 64.3 \\ 1993-1997: & 64.0 \\ 1998-2002: & 64.0\end{array}$

D. Percent Justices appointed from the lower courts --

$\begin{array}{ll}1973-1982: & 0.42 \\ 1983-1992: & 0.42 \\ 1993-1997: & 0.29 \\ 1998-2002: & 0.36\end{array}$

E. Percent Justices appointed from the bar -

$\begin{array}{ll}1973-1982: & 0.35 \\ 1983-1992: & 0.31 \\ 1993-1997: & 0.29 \\ 1998-2002: & 0.29\end{array}$

Source: Nihon minshu horitsuka kyokai, ed., Zen saibankan keireki soran dai 4 ban [Overview of Careers of All Japanese Judges, 4th ed.] (Tokyo: Konin sha, 2004). 
Table 2: Appointments to the Supreme Court, 1983-2005

\begin{tabular}{|c|c|c|c|c|c|c|c|c|}
\hline $\begin{array}{l}\text { Prime } \\
\text { Minister }\end{array}$ & Justice & Born & Appointed & $\begin{array}{l}\text { Apprx } \\
\text { Age }\end{array}$ & Prior Job & $\begin{array}{l}\text { Chief } \\
\text { Justice? }\end{array}$ & $\begin{array}{l}\text { Secretariat } \\
\text { post? }\end{array}$ & $\begin{array}{l}\text { Secretary- } \\
\text { General? }\end{array}$ \\
\hline Nakasone & Tsunoda & 1920 & 1983 & 63 & bureaucrat & & & \\
\hline Nakasone & Takashima & 1919 & 1984 & 65 & bureaucrat & & & \\
\hline Nakasone & Yaguchi & 1920 & 1984 & 64 & judge & yes & yes & yes \\
\hline Nakasone & Shimatani & 1920 & 1984 & 64 & lawyer & & & \\
\hline Nakasone & Nagashima & 1918 & 1984 & 66 & prosecutor & & & \\
\hline Nakasone & Oouchi & 1922 & 1985 & 63 & judge & no & yes & yes \\
\hline Nakasone & Fujishima & 1924 & 1985 & 61 & prosecutor & & & \\
\hline Nakasone & Kagawa & 1921 & 1986 & 65 & judge & no & no & no \\
\hline Nakasone & Sato & 1920 & 1986 & 66 & lawyer & & & \\
\hline Nakasone & Sakaue & 1923 & 1986 & 63 & lawyer & & & \\
\hline Nakasone & Hayashi & 1923 & 1986 & 63 & lawyer & & & \\
\hline Nakasone & Yotsuya & 1922 & 1987 & 65 & judge & no & yes & yes \\
\hline Nakasone & Okuno & 1920 & 1987 & 67 & lawyer & & & \\
\hline Takeshita & Teika & 1923 & 1988 & 65 & judge & no & no & no \\
\hline Takeshita & Oohori & 1925 & 1988 & 63 & prosecutor & & & \\
\hline Kaifu & Sonobe & 1929 & 1989 & 60 & judge & no & no & no \\
\hline Kaifu & Kusaba & 1925 & 1989 & 64 & judge & yes & yes & yes \\
\hline Kaifu & Mimura & 1924 & 1990 & 66 & bureaucrat & & & \\
\hline Kaifu & Nakajima & 1925 & 1990 & 65 & bureaucrat & & & \\
\hline Kaifu & Kabe & 1927 & 1990 & 63 & judge & no & yes & yes \\
\hline Kaifu & Hashimoto & 1922 & 1990 & 68 & lawyer & & & \\
\hline Kaifu & Sato & 1924 & 1990 & 66 & lawyer & & & \\
\hline Kaifu & Kizaki & 1924 & 1990 & 66 & lawyer & & & \\
\hline Miyazawa & Oonishi & 1928 & 1991 & 63 & judge & no & yes & yes \\
\hline Miyazawa & Ono & 1930 & 1992 & 62 & judge & no & yes & no \\
\hline Miyazawa & Miyoshi & 1927 & 1992 & 65 & judge & yes & yes & no \\
\hline Miyazawa & Oono & 1927 & 1993 & 66 & lawyer & & & \\
\hline Miyazawa & Ooshiro & na & 1993 & na & lawyer & & & \\
\hline
\end{tabular}


Table 2 (Cont'd)

\begin{tabular}{|c|c|c|c|c|c|c|c|c|}
\hline $\begin{array}{l}\text { Prime } \\
\text { Minister }\end{array}$ & Justice & Born & Appointed & $\begin{array}{l}\text { Apprx } \\
\text { Age }\end{array}$ & Prior Job & $\begin{array}{l}\text { Chief } \\
\text { Justice? }\end{array}$ & $\begin{array}{l}\text { Secretariat } \\
\text { post? }\end{array}$ & $\begin{array}{l}\text { Secretary- } \\
\text { General? }\end{array}$ \\
\hline Hosokawa & Chigusa & 1932 & 1993 & 61 & judge & no & yes & yes \\
\hline Hosokawa & Takahashi & 1927 & 1994 & 67 & bureaucrat & & & \\
\hline Hosokawa & Ozaki & 1929 & 1994 & 65 & lawyer & & & \\
\hline Hosokawa & Negishi & 1928 & 1994 & 66 & prosecutor & & & \\
\hline Murayama & Kawai & 1932 & 1994 & 62 & lawyer & & & \\
\hline Murayama & Fukuda & 1935 & 1995 & 60 & bureaucrat & & & \\
\hline Murayama & Fujii & 1932 & 1995 & 63 & judge & no & no & no \\
\hline Murayama & Endo & 1930 & 1995 & 65 & lawyer & & & \\
\hline Murayama & Ijima & 1932 & 1995 & 63 & prosecutor & & & \\
\hline Hashimoto & Oode & 1932 & 1997 & 65 & bureaucrat & & & \\
\hline Hashimoto & Kanatani & 1935 & 1997 & 62 & judge & no & yes & yes \\
\hline Hashimoto & Yamaguchi & 1932 & 1997 & 65 & judge & yes & yes & yes \\
\hline Hashimoto & Motohara & 1931 & 1997 & 66 & lawyer & & & \\
\hline Obuchi & Kitagawa & 1934 & 1998 & 64 & judge & no & yes & no \\
\hline Obuchi & Kameyama & 1934 & 1998 & 64 & prosecutor & & & \\
\hline Obuchi & Kajitani & 1935 & 1999 & 64 & lawyer & & & \\
\hline Obuchi & Okuda & 1932 & 1999 & 67 & professor & & & \\
\hline Obuchi & Machida & 1936 & 2000 & 64 & judge & yes & yes & no \\
\hline Mori & Fukazawa & 1934 & 2000 & 66 & lawyer & & & \\
\hline Koizumi & Yokoo & 1941 & 2001 & 60 & bureaucrat & & & \\
\hline Koizumi & Hamada & 1936 & 2001 & 65 & lawyer & & & \\
\hline Koizumi & Ueda & 1937 & 2002 & 65 & judge & no & yes & no \\
\hline Koizumi & Shimada & 1938 & 2002 & 64 & judge & no & yes & no \\
\hline Koizumi & Izumi & 1939 & 2002 & 63 & judge & no & yes & yes \\
\hline Koizumi & Takii & 1936 & 2002 & 66 & lawyer & & & \\
\hline Koizumi & Fujita & 1940 & 2002 & 62 & professor & & & \\
\hline Koizumi & Kainaka & 1940 & 2002 & 62 & prosecutor & & & \\
\hline Koizumi & Tsuno & 1938 & 2004 & 66 & bureaucrat & & & \\
\hline Koizumi & Saiguchi & 1938 & 2004 & 66 & lawyer & & & \\
\hline Koizumi & Imai & 1939 & 2004 & 65 & judge & & yes & no \\
\hline Koizumi & Nakegawa & 1939 & 2005 & 66 & lawyer & & & \\
\hline Koizumi & Horigome & 1940 & 2005 & 65 & judge & & yes & yes \\
\hline Koizumi & Furuta & 1942 & 2005 & 63 & prosecutor & & & \\
\hline
\end{tabular}

Notes: The 2005 court is in italics. Chief justices are in boldface. Koizumi's first eight appointments (a court majority) are between horizontal lines. The last column indicates whether the justice had been secretary-general of the secretariat.

Sources: Nihon minshu horitsuka kyokai, ed., Zen saibankan keireki soran dai 4 ban [Overview of Careers of All Japanese Judges, 4th ed.] (Tokyo: Konin sha, 2004); Supreme Court of Japan, http://courtdomino2. courts.go.jp/home.nsf/ehome?openPage. 
Table 3: Lower Court Judges Appointed in 1968, 1978, 1988, and 1998: Selected Statistics

A. Number appointed --

$\begin{array}{lll}\text { Class of 1968: } & 86 \text { (93\% male) } \\ \text { Class of 1978: } & 82 \text { (93\% male) } \\ \text { Class of 1988: } & 79 \text { (91\% male) } \\ \text { Class of 1998: } & 94 \text { (81\% male) }\end{array}$

B. $\quad$ University of Tokyo graduates --

$\begin{array}{ll}\text { Class of 1968: } & 29.1 \\ \text { Class of 1978: } & 17.1 \\ \text { Class of 1988: } & 20.3 \\ \text { Class of 1998: } & 17.0\end{array}$

C. $\quad$ University of Kyoto graduates --

$\begin{array}{lc}\text { Class of 1968: } & 10.5 \\ \text { Class of 1978: } & 13.4 \\ \text { Class of 1988: } & 2.5 \\ \text { Class of 1998: } & 0\end{array}$

D. Mean times flunking the LRTI entrance exam --

$\begin{array}{ll}\text { Class of 1968: } & 4.4 \\ \text { Class of 1978: } & 4.6 \\ \text { Class of 1988: } & 4.9 \\ \text { Class of 1998: } & 3.5\end{array}$

E. $\quad$ oppointed initially to the Tokyo District Court -Class of 1968: 18.8 Class of 1978: $\quad 19.2$ Class of 1988: $\quad 31.5$

Class of 1998: $\quad 30.1$

F. $\quad$ oppointed initially to branch office or summary court -Class of 1968: 12.9 Class of 1978: $\quad 2.6$ Class of 1988: 0 Class of 1998: 0

G. $\quad$ members of the Young Jurists League --

$\begin{array}{lc}\text { Class of 1968: } & 11.6 \\ \text { Class of 1978: } & 0 \\ \text { Class of 1988: } & 0 \\ \text { Class of 1998: } & 0\end{array}$

Sources: Nihon minshu horitsuka kyokai, ed., Zen saibankan keireki soran dai 4 ban [Overview of Careers of All Japanese Judges, 4th ed.] (Tokyo: Konin sha, 2004); We obtained the YJL roster from Shiso undo kenkyu sho, ed., Osorubeki saiban [Fearsome Trials] (Tokyo: Zenbo sha, 1969); Gakushikai, Kaiinshi meiroku: Heisei 10 nen yo [Membership Roster: For 1998 Use] (Tokyo: Gakushikai, 1997 ). 
Table 4: Initial Appointment to the Tokyo District Court

\section{A. $\quad$ Fraction of Class Starting at Tokyo District Court}

\begin{tabular}{lcc} 
& Pre-1993 & Post-1993 \\
\hline U Tokyo graduates & .30 & .63 \\
Non-U Tokyo graduates & .16 & .23 \\
U Kyoto graduates & .23 & $\star$ \\
$\quad$ Non-U Kyoto graduates & .18 & .35 \\
Flunks $<5$ & .24 & .19 \\
Flunks $>4$ & .10 & .32
\end{tabular}

Notes: * No U Kyoto graduates in the class of 1998.

The pre-1993 column details the first postings of the classes of 1958, 1968, 1978, and 1988; the post-1993 column details the first postings of the class of 1998 .

B. Determinants of Starting at the Tokyo District Court

\begin{tabular}{|c|c|c|c|c|c|}
\hline U Tokyo & $\begin{array}{l}.117 \star \star \\
(1.91)\end{array}$ & $\mathrm{Cl}-98$ & * & U Tokyo & $\begin{array}{l}.288 \\
(1.54)\end{array}$ \\
\hline U Kyoto ${ }^{a}$ & $\begin{array}{c}.022 \\
(0.31)\end{array}$ & & & & \\
\hline Flunks & $\begin{array}{l}-.034 * \star \star \\
(3.17)\end{array}$ & $\mathrm{Cl}-98$ & * & Flunks & $\begin{array}{r}-.035 \\
(1.48)\end{array}$ \\
\hline Male & $\begin{array}{l}-.019 \\
(0.23)\end{array}$ & $\mathrm{Cl}-98$ & $\star$ & Male & $\begin{array}{l}.226 * \\
(1.73)\end{array}$ \\
\hline
\end{tabular}

n 424

Adjusted R2 $\quad .04$

Notes: Dependent variable $=1$ if initial appointment is to the Tokyo District Court. The regression is probit. The table gives the marginal effects calculated at the median, followed by the absolute value of z-statistic. The adjusted R2 is calculated for the analogous regression in OLS. * Significant at

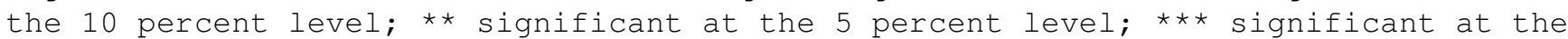
1 percent level. Even for the classes of 1958 and 68, YJL membership did not affect initial appointments.

a No U Kyoto graduates were in the class of 1998.

Sources: See Table 3 . 
Table 5: Years 5-15 Appointments

A. Fraction of Years 5-15 in Administrative Posts

\begin{tabular}{|c|c|c|}
\hline & Pre-1993 & Post -1993 \\
\hline TDC Starters & .28 & .30 \\
\hline Non-TDC Starters & .06 & .08 \\
\hline U Tokyo graduates & .16 & .20 \\
\hline Non-U Tokyo graduates & .08 & .14 \\
\hline U Kyoto graduates & .15 & $\star$ \\
\hline Non-U Kyoto graduates & .10 & \\
\hline Flunks $<5$ & .12 & .23 \\
\hline Flunks $>4$ & .06 & .06 \\
\hline Non-YJL Members & .10 & $\star \star$ \\
\hline YJL Members & .09 & \\
\hline Men & .11 & .16 \\
\hline Women & .03 & .10 \\
\hline
\end{tabular}

Notes: * Only 1 graduate. * No members in this age bracket.

The pre-1993 column details the careers of the class of 1968 during 1973-1983 and the class of 1978 during 1983-1993; the post-1993 column details the careers of the class of 1988 during 1993-2003.

B. Eraction of Years 5-15 in Branch Offices or Summary Courts

\begin{tabular}{|c|c|c|}
\hline & Pre-1993 & Post -1993 \\
\hline TDC Starters & .15 & .19 \\
\hline Non-TDC Starters & .35 & .28 \\
\hline U Tokyo graduates & .24 & .29 \\
\hline Non-U Tokyo graduates & .33 & .24 \\
\hline U Kyoto graduates & .27 & * \\
\hline Non-U Kyoto graduates & .31 & \\
\hline Flunks $<5$ & .27 & .19 \\
\hline Flunks $>4$ & .39 & .31 \\
\hline Non-YJL Members & .30 & $\star \star$ \\
\hline YJL Members & .35 & \\
\hline Men & .32 & .25 \\
\hline Women & .19 & .20 \\
\hline
\end{tabular}

Notes: * Only 1 graduate. $*$ No members in this age bracket.

The pre-1993 column details the careers of the class of 1968 during 1973-1983 and the class of 1978 during 1983-1993; the post-1993 column details the careers of the class of 1988 during 1993-2003. 


\section{Ramseyer \& Rasmusen: Page 36}

\section{Table 5 (Cont'd)}

C. Determinants of Administrative Appointments

$\begin{array}{lc}\text { YJL }^{2} & -.026 \\ \text { U Tokyo } & (1.51) \\ \text { U Kyoto } & .035 \\ \text { Flunks } & (1.21) \\ \text { Male } & (0.27) \\ \text { st TDC } & -.005 \\ & (1.44) \\ \text { n } & .046 \star \star \star \\ \text { Adjusted R2 } & (2.70) \\ .191 * \star \star \\ (3.49) \\ \end{array}$

$$
\begin{array}{cc}
\mathrm{Cl}-88 \text { * U Tokyo } & .009 \\
\mathrm{Cl}-88 \text { * U Kyoto } & .622 * \star \\
& (2.07) \\
\mathrm{Cl}-88 \text { * Flunks } & -.012 \\
& (1.64) \\
\mathrm{Cl}-88 \text { * Male } & .083 \\
& (1.23) \\
\mathrm{Cl}-88 * 1^{\text {st }} \text { TDC } & -.005 \\
& (0.14)
\end{array}
$$

Notes: The dependent variable gives the fraction of the time during years 515 of a judge's career that he spends in an administrative post.

\begin{tabular}{|c|c|c|c|c|}
\hline $\mathrm{YJL}^{\mathrm{a}}$ & $\begin{array}{l}.101 * \\
(2.02)\end{array}$ & & & \\
\hline U Tokyo & $\begin{array}{l}-.048 \\
(1.13)\end{array}$ & $\mathrm{Cl}-88$ & * U Tokyo & $\begin{array}{c}.118 \\
(1.39)\end{array}$ \\
\hline U Kyoto & $\begin{array}{l}-.001 \\
(0.02)\end{array}$ & $\mathrm{Cl}-88$ & * U Kyoto & $\begin{array}{l}-.331 * \star \star \\
(13.17)\end{array}$ \\
\hline Flunks & $\begin{array}{l}.024 * \star \star \\
(5.51)\end{array}$ & $\mathrm{Cl}-88$ & * Flunks & $\begin{array}{l}.003 \\
(0.35)\end{array}$ \\
\hline Male & $\begin{array}{l}.142 \star \star \star \\
(2.77)\end{array}$ & $\mathrm{Cl}-88$ & * Male & $\begin{array}{l}-.106 * \\
(1.83)\end{array}$ \\
\hline $1^{\text {st }} \mathrm{TDC}$ & $\begin{array}{l}-.165 \star \star \star \\
(4.21)\end{array}$ & $\mathrm{Cl}-88$ & $\star 1^{\text {st }} \mathrm{TDC}$ & $\begin{array}{c}.084 \\
(1.03)\end{array}$ \\
\hline $\mathrm{n}$ & 239 & & & \\
\hline Adjusted R2 & .26 & & & \\
\hline
\end{tabular}

The regression is tobit. Censoring: $(179,58,2)$. The table gives the marginal effects calculated at the median, followed by the absolute value of $t-$ statistic. The adjusted R2 is calculated for the analogous regression in OLS. *

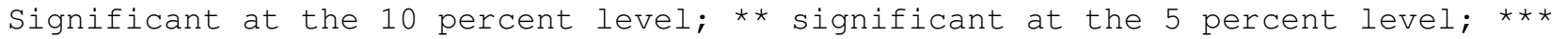
significant at the 1 percent level.

${ }^{a}$ No members of the class of 1988 were members of the YJL.

D. Determinants of Branch Office Appointments

Notes: The dependent variable gives the fraction of the time during years 515 of a judge's career that he spends in a branch office or summary court.

The regression is tobit. Censoring: $(59,177,3)$. The table gives the marginal effects calculated at the median, followed by the absolute value of tstatistic. The adjusted R2 is calculated for the analogous regression in OLS. Significant at the 10 percent level; ** significant at the 5 percent level; $* \star *$ significant at the 1 percent level.

${ }^{a}$ No members of the class of 1988 were members of the YJL.

Sources: See Table 3 . 


\section{Table 6: Years 15-25 Appointments}

\section{A. Fraction of Years 15-25 in Administrative Posts}

\begin{tabular}{lcc} 
& Pre-1993 & Post-1993 \\
\hline TDC Starters & .61 & .62 \\
Non-TDC Starters & .32 & .27 \\
U Tokyo graduates & .44 & .34 \\
$\quad$ Non-U Tokyo graduates & .33 & .32 \\
U Kyoto graduates & .56 & .55 \\
$\quad$ Non-U Kyoto graduates & .40 & .32 \\
Flunks $<5$ & .26 & .31 \\
$\quad$ Flunks > 4 & .38 & $*$ \\
Non-YJL Members & .30 & .34 \\
$\quad$ YJL Members & .37 & .08
\end{tabular}

Notes: * No members in this age bracket.

The pre-1993 column details the careers of the class of 1958 during 1973-1983 and the class of 1968 during 1983-1993; the post-1993 column details the careers of the class of 1978 during 1993-2003.

B. Fraction of Years 15-25 in Branch Offices or Summary Courts

\begin{tabular}{|c|c|c|}
\hline & Pre-1993 & Post-1993 \\
\hline TDC Starters & .08 & .04 \\
\hline Non-TDC Starters & .21 & .27 \\
\hline U Tokyo graduates & .11 & .19 \\
\hline Non-U Tokyo graduates & .22 & .22 \\
\hline U Kyoto graduates & .07 & .14 \\
\hline Non-U Kyoto graduates & .21 & .23 \\
\hline Flunks $<5$ & .16 & .16 \\
\hline Flunks $>4$ & .27 & .36 \\
\hline Non-YJL Members & .18 & * \\
\hline YJL Members & .21 & \\
\hline Men & .19 & .20 \\
\hline Women & .15 & .44 \\
\hline
\end{tabular}

Notes: * No members in this age bracket.

The pre-1993 column details the careers of the class of 1958 during 1973-1983 and the class of 1968 during 1983-1993; the post-1993 column details the careers of the class of 1978 during 1993-2003. 


\section{Ramseyer \& Rasmusen: Page 38}

\section{Table 6 (Cont'd)}

C. Determinants of Administrative Appointments

\begin{tabular}{|c|c|}
\hline $\mathrm{YJL}^{\mathrm{a}}$ & $\begin{array}{c}-.114 * \star \\
(2.58)\end{array}$ \\
\hline U Tokyo & $\begin{array}{l}.119 * \\
(1.87)\end{array}$ \\
\hline U Kyoto & $\begin{array}{l}.237 \star \star \star \\
(3.14)\end{array}$ \\
\hline Flunks & $\begin{array}{l}-.003 \\
(0.39)\end{array}$ \\
\hline Male & $\begin{array}{l}.197 \star \star \star \\
(3.25)\end{array}$ \\
\hline $1^{\text {st }} \mathrm{TDC}$ & $\begin{array}{l}.210 \star \star \star \\
(2.84)\end{array}$ \\
\hline $\mathrm{n}$ & 218 \\
\hline Adjusted R2 & .21 \\
\hline
\end{tabular}

$$
\begin{aligned}
& \mathrm{Cl}-78 \text { * U Tokyo -.072 } \\
& \mathrm{Cl}-78 \text { * U Kyoto }-.032 \\
& \text { Cl-78 } 1 \text { Elunks } \\
& -.031 \\
& \mathrm{Cl}-78 \text { * Male } \quad .055 \\
& \mathrm{Cl}-78 * 1^{\mathrm{st}} \mathrm{TDC} \quad .057
\end{aligned}
$$

Adjusted R2

.21

Notes: The dependent variable gives the fraction of the time during years 15-25 of a judge's career that he spends in an administrative post.

The regression is tobit. Censoring: $(68,143,7)$. The table gives the marginal effects calculated at the median, followed by the absolute value of $t-$

\begin{tabular}{|c|c|c|c|c|c|c|c|}
\hline $\mathrm{YJL}^{\mathrm{a}}$ & $\begin{array}{l}.056 \\
(1.07)\end{array}$ & & & & & & \\
\hline U Tokyo & $\begin{array}{l}-.097 \star \star \star \\
(2.14)\end{array}$ & & $\mathrm{Cl}-78$ & * & $\mathrm{U} \mathrm{I}$ & Tokyo & $\begin{array}{l}.065 \\
(0.52)\end{array}$ \\
\hline U Kyoto & $\begin{array}{l}-.145 \star \star \star \\
(3.24)\end{array}$ & & $\mathrm{C} 1-78$ & * & $\mathrm{U} \mathrm{K}$ & Kyoto & $\begin{array}{l}.173 \\
(1.00)\end{array}$ \\
\hline Flunks & $\begin{array}{l}.011 \\
(1.53)\end{array}$ & $\mathrm{Cl}-78$ & * Flun & $\mathrm{ks}$ & & & $\begin{array}{l}.028 * \\
(1.73)\end{array}$ \\
\hline Male & $\begin{array}{l}.015 \\
(0.21)\end{array}$ & $\mathrm{Cl}-78$ & * Male & & & & $\begin{array}{l}-.091 \\
(1.36)\end{array}$ \\
\hline $1^{\text {st }} \operatorname{TDC}$ & $\begin{array}{l}-.110 * \star \\
(2.16)\end{array}$ & & $\mathrm{Cl}-78$ & * & $1^{\text {st }}$ & TDC & $\begin{array}{l}-.139 * \\
(1.84)\end{array}$ \\
\hline $\mathrm{n}$ & 218 & & & & & & \\
\hline Adjusted R2 & .13 & & & & & & \\
\hline
\end{tabular}
statistic. The adjusted R2 is calculated for the analogous regression in OLS. *

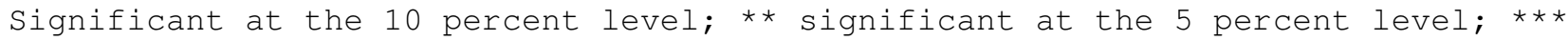
significant at the 1 percent level.

${ }^{a}$ No members of the class of 1978 were members of the YJL.

D. Determinants of Branch Office Appointments

Notes: The dependent variable gives the fraction of the time during years 15-25 of a judge's career that he spends in branch offices or summary courts.

The regression is tobit. Censoring: $(116,100,2)$. The table gives the marginal effects calculated at the median, followed by the absolute value of tstatistic. The adjusted R2 is calculated for the analogous regression in OLS.

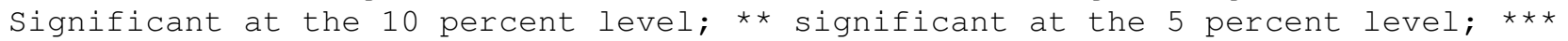
significant at the 1 percent level.

${ }^{a}$ No members of the class of 1978 were members of the YJL.

Sources: See Table 3 . 
Table 7: Years 25-35 Appointments

\section{A. Fraction of Years 25-35 in Administrative Posts}

\begin{tabular}{|c|c|c|}
\hline & Pre-1993 & Post-1993 \\
\hline TDC starters & .63 & .79 \\
\hline Non-TDC Starters & .63 & .49 \\
\hline U Tokyo graduates & .60 & .61 \\
\hline Non-U Tokyo graduates & .65 & .55 \\
\hline U Kyoto graduates & .60 & .85 \\
\hline Non-U Kyoto graduates & .65 & .53 \\
\hline Flunks $<5$ & .65 & .63 \\
\hline Flunks > 4 & .58 & .37 \\
\hline Non-YJL Members & .69 & .60 \\
\hline YJL Members & .50 & .48 \\
\hline Men & * & .57 \\
\hline Women & & .48 \\
\hline
\end{tabular}

B. Fraction of Years 25-35 in Branch Offices or Summary Courts

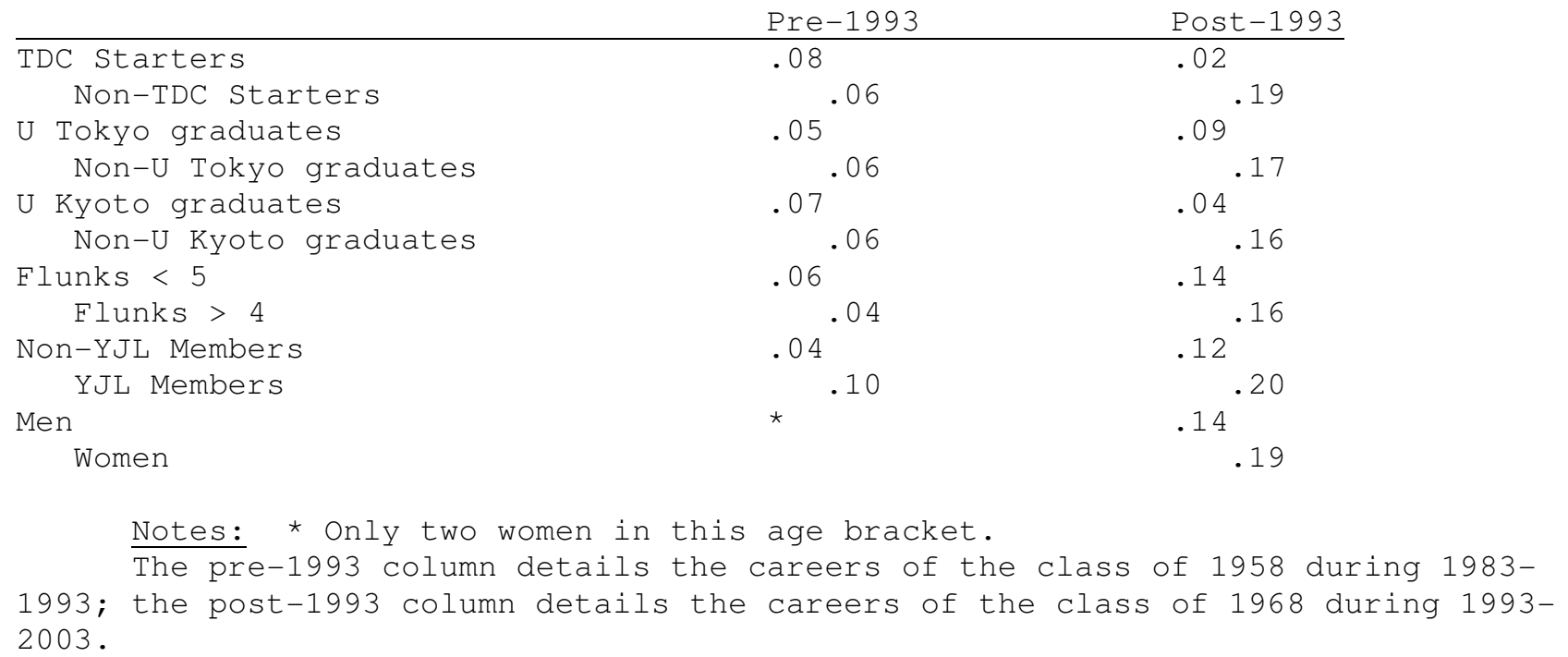




\section{Ramseyer \& Rasmusen: Page 40}

\section{Table 7 (Cont'd)}

C. Determinants of Administrative Appointments

$\begin{array}{lc}\text { YJL } & -.175 * \\ \text { U Tokyo } & (1.78) \\ & -.086 \\ \text { U Kyoto } & (0.62) \\ \text { Flunks } & -.124 \\ \text { Male } & (1.11) \\ \text { st TDC } & -.027 \\ & (1.16) \\ & .298 * \\ \text { n Adjusted R2 } & (2.10) \\ \text { Ad } & -.028 \\ & (0.15) \\ \end{array}$

$$
\begin{aligned}
& \mathrm{Cl}-68 \text { * YJL } \quad .028 \\
& \mathrm{Cl}-68 \text { * U Tokyo } .104 \\
& \text { Cl-68 * U Kyoto } \\
& .283 * \star \\
& \text { (2.21) } \\
& \text { Cl-68*Flunks } \\
& -.012 \\
& (0.47) \\
& \text { Cl-68* Male }-.153 \\
& \mathrm{Cl}-68 * 1^{\text {st }} \mathrm{TDC}
\end{aligned}
$$

Notes: The dependent variable gives the fraction of the time during years $25-35$ of a judge's career that he spends in an administrative post.

The regression is tobit. Censoring: $(17,84,33)$. The table gives the marginal effects calculated at the median, followed by the absolute value of t-statistic. The adjusted R2 is calculated for the analogous regression in OLS. * Significant at the

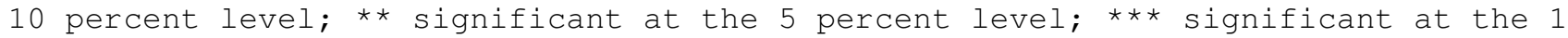
percent level.

D. Determinants of Branch Office Appointments

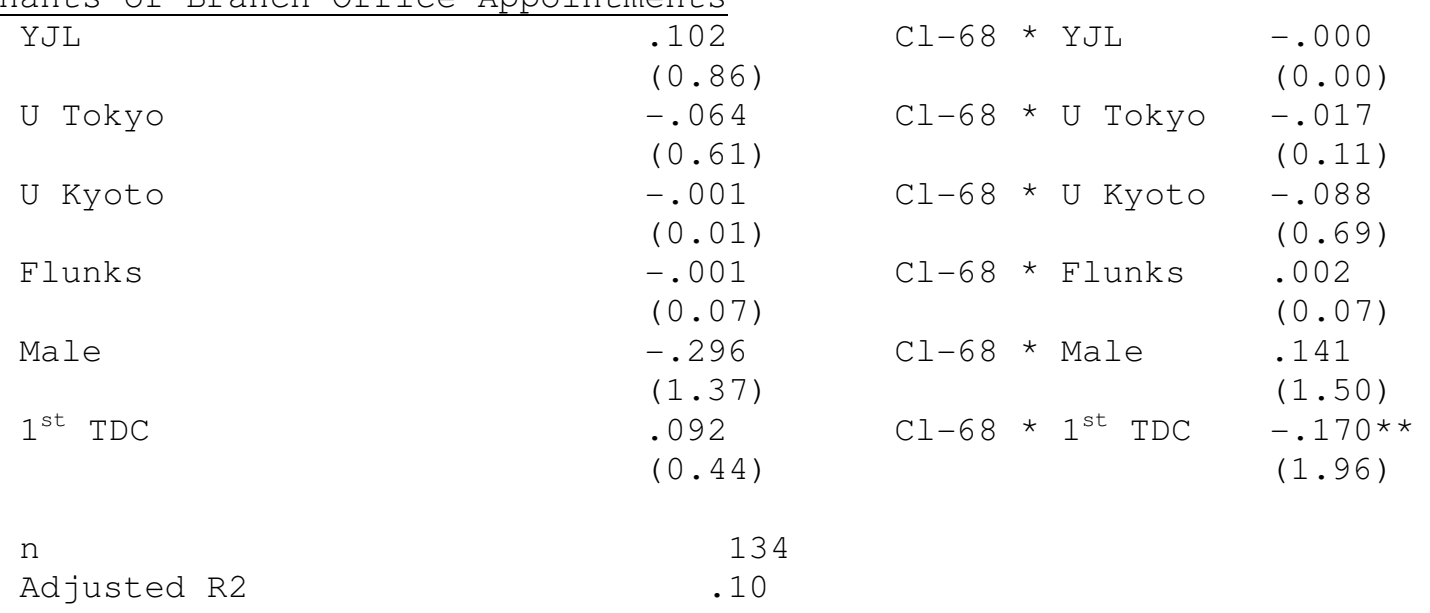

Notes: The dependent variable gives the fraction of the time during years 25-35 of a judge's career that he spends in branch offices or summary courts.

The regression is tobit. Censoring: $(98,35,1)$. The table gives the marginal effects calculated at the median, followed by the absolute value of t-statistic. The adjusted R2 is calculated for the analogous regression in OLS. * Significant

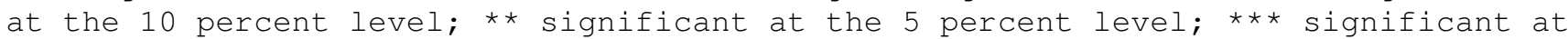
the 1 percent level. 
Ramseyer \& Rasmusen: Page 41

Table 8: The Alternating Parties Theory

Opposition

Managed Judges

$(10,0)$

Incumbent

Independent and Unbiased Judges

$(8,6)$

Independent but Biased Judges

$(5,5)$ 